\title{
Sucrose Utilization for Improved Crop Yields: A Review Article
}

\author{
Oluwaseun Olayemi Aluko ${ }^{1,2} \mathbb{D}$, Chuanzong $\mathrm{Li}^{1,2}$, Qian Wang ${ }^{1, *}$ and Haobao Liu ${ }^{1, *}$ \\ 1 Tobacco Research Institute of Chinese Academy of Agricultural Sciences, Qingdao 266101, China; \\ aluko.oluseun@gmail.com (O.O.A.); lcz911006@163.com (C.L.) \\ 2 Graduate School of Chinese Academy of Agricultural Sciences, Beijing 100081, China \\ * Correspondence: wangqian01@caas.cn (Q.W.); liuhaobao@caas.cn (H.L.); \\ Tel.: +86-0532-8870-1031 (Q.W.); +86-0532-8870-1829 (H.L.)
}

check for updates

Citation: Aluko, O.O.; Li, C.; Wang, Q.; Liu, H. Sucrose Utilization for Improved Crop Yields: A Review Article. Int. J. Mol. Sci. 2021, 22, 4704. https://doi.org/10.3390/ijms22094704

Academic Editor: Iwona Morkunas

Received: 2 March 2021

Accepted: 17 April 2021

Published: 29 April 2021

Publisher's Note: MDPI stays neutral with regard to jurisdictional claims in published maps and institutional affiliations.

Copyright: (c) 2021 by the authors. Licensee MDPI, Basel, Switzerland. This article is an open access article distributed under the terms and conditions of the Creative Commons Attribution (CC BY) license (https:// creativecommons.org/licenses/by/ $4.0 /)$.

\begin{abstract}
Photosynthetic carbon converted to sucrose is vital for plant growth. Sucrose acts as a signaling molecule and a primary energy source that coordinates the source and sink development. Alteration in source-sink balance halts the physiological and developmental processes of plants, since plant growth is mostly triggered when the primary assimilates in the source leaf balance with the metabolic needs of the heterotrophic sinks. To measure up with the sink organ's metabolic needs, the improvement of photosynthetic carbon to synthesis sucrose, its remobilization, and utilization at the sink level becomes imperative. However, environmental cues that influence sucrose balance within these plant organs, limiting positive yield prospects, have also been a rising issue over the past few decades. Thus, this review discusses strategies to improve photosynthetic carbon assimilation, the pathways actively involved in the transport of sucrose from source to sink organs, and their utilization at the sink organ. We further emphasize the impact of various environmental cues on sucrose transport and utilization, and the strategic yield improvement approaches under such conditions.
\end{abstract}

Keywords: photosynthetic carbon assimilation; source-to-sink relationship; sucrose transporters; sucrose utilization; environmental factors; sucrose transports

\section{Introduction}

Plant growth and development are adversely affected when photo-assimilates are not appropriately apportioned. A balanced distribution and allocation of carbon (C) to various plant organs is crucial for plant growth, since the translocation of carbohydrates from the photosynthesizing "source" leaves provide substrates required for the growth of nonphotosynthesizing "sink" organs. During photosynthesis, carbon dioxide $\left(\mathrm{CO}_{2}\right)$ can be efficiently converted into 3-phosphoglyceric acid and glyceraldehyde-3-phosphate, which act as a precursor for starch and sucrose biosynthesis. A portion of the plant photosynthates is stored in the form of starch within the chloroplast. At night, these stored reserves are remobilized as sucrose to support plant growth and metabolism [1,2]. Sucrose is the transportable form of carbon predominantly utilized at the sink to supply the energy required for plant biomass production [3].

Sucrose also acts as the signaling molecule that coordinates roots (sink) and shoots (mainly source) development [4,5]. Alteration in the sucrose source-sink balance impedes plant growth and development [6]. Plant growth is greatly enhanced when the primary assimilates in the source tissues balance with the metabolic needs of the heterotrophic sinks. The translocation of photo-assimilate to the sink and its utilization at the sink level is mainly altered by environmental factors. However, little attention has been directed toward the influence of these environmental factors on photo-assimilate transport and utilization at the sink level. Thus, a conceptual understanding of the source-sink interaction is paramount for optimizing plant growth under fluctuating environmental conditions. To fully understand the interaction between the partitioning of photo-assimilates, plant 
growth, and environment (Figure 1), the following sections focus on: (1) strategies to improve the capacity and efficiency of photosynthetic $C$ assimilation, (2) how changes in sucrose utilization when manipulating photosynthesis affect plant growth, (3) sucrose transport from the source to the sink organs, and (4) utilization of sucrose at the sink organs. We also summarized the impact of environmental cues on the translocation of sucrose to the sink and its utilization at the sink level. In addition, the strategic approaches involved in crop-yield improvement are discussed.

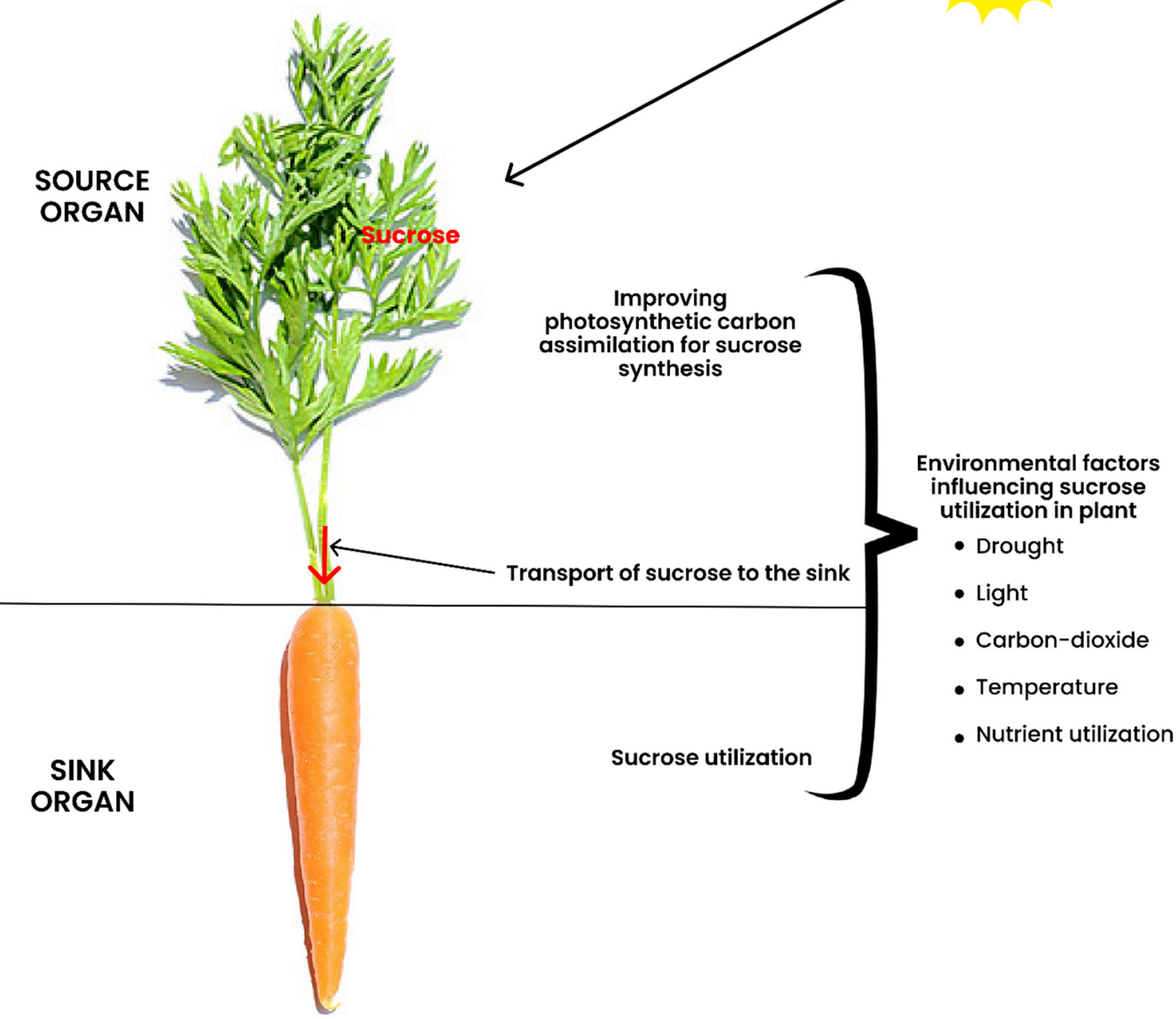

Figure 1. Sucrose utilization at the source and sink level. To fully optimize crop yields through sucrose utilization, improving photosynthetic carbon assimilation for sucrose synthesis, transport of sucrose to the sink, and its utilization at the sink level become imperative. Given the efficient utilization of sucrose, other environmental factors can disrupt sucrose distribution within plant organs.

\section{The Definition of Terminologies in Source-to-Sink Interaction}

Manson and Maskell proposed "source and sink" in plants a few decades ago [7]. The terms "source production" and "sink utilization" of photo-assimilates are now frequently used in research related to plant resource allocation. "Source" tissue is the producer and exporter of photo-assimilates, while "sink" tissue is the importer and consumer of the assimilates [8]. Examples of source tissues of carbon (C) are fully expanded (older) leaves and green parts of plants, whereas sink tissues are roots, tubers, fruits, and seeds. Of all sink 
tissues, roots are the major putative source of inorganic nitrogen $(\mathrm{N})$, whereas fully mature leaves are the main producers of organic nitrogen. The developing tubers/fruits/seeds serve as sinks for organic and inorganic N. Another term used in source-sink interaction is mass-flow, a transport system that links the source with the sink organ. In this context, flow refers to the xylem and phloem transport systems. The phloem sieve tube is involved in the movement of most organic nutrients basipetally to the sink organ, whereas the xylem transports nutrients from the sink to the source tissues [9].

\section{Improving the Capacity and Efficiency of Photosynthetic Carbon Assimilation}

Efficient photosynthetic carbon (C) assimilation is crucial for the overall yield of the reproductive sink organs [10]. One of the major bottlenecks of photosynthesis is the reaction of enzyme ribulose-1, 5-bisphosphate carboxylase/oxygenase (RuBisCO) with oxygen, leading to photorespiration, which reduces the efficiency of photosynthesis. RuBisCO has a slow catalytic rate of fixing $\mathrm{CO}_{2}$ with a turnover frequency of 3-10 per second [11] compared to most enzymes. Furthermore, RuBisCO demands a substantial amount of $\mathrm{N}$ and water from the plant, consuming $25 \%$ of $\mathrm{N}$ in a typical C3 plant. As such, reducing photorespiration is a prerequisite to improving photosynthetic efficiency, since improved photosynthetic efficiency is strongly related to water-use efficiency (WUE) and N-use efficiency (NUE). When the stomata open in $\mathrm{C} 3$ plants, $\mathrm{CO}_{2}$ moves in, and oxygen $\left(\mathrm{O}_{2}\right)$ exits the cells. Upon closure of the stomata aperture under dry and harsh conditions, $\mathrm{O}_{2}$ accumulates to reduce the efficiency of the $\mathrm{C} 3$ pathway. Any component that indirectly influences stomatal conductance, such as root architecture, may increase water availability and promote $\mathrm{C}$ assimilation [12]. A reduction in stomatal resistance via the opening of the stomata aperture promotes higher $\mathrm{CO}_{2}$ uptake for photosynthetic $\mathrm{C}$ input at the expense of substantial water loss and adversely affects plants in semiarid or arid environments [13]. However, improving the conductance of $\mathrm{CO}_{2}$ from the substomatal spaces to Rubisco should possibly increase photosynthesis without adversely affecting water use [14]. Some other plants that have evolved adaptation to withstand harsh and dry conditions are $\mathrm{C} 4$ and crassulacean acid metabolism (CAM) plants. The $\mathrm{C} 4$ photosynthetic mechanism allows plants to pump $\mathrm{CO}_{2}$ into specialized cells in the bundle sheath cells to shield plants from the clusters of oxygen that might result from stomatal closure during dry conditions $[14,15]$. This allows $\mathrm{C}_{4}$ plants to withstand habitats that may be too harsh for $C_{3}$ species because of their improved water- and nutrient-use efficiency [16,17]. Genetic approaches have also been established to pinpoint the anatomical development of C4 (Kranz anatomy), but the introduction of the functional C4 system has become a dilemma. If this is obtainable, the introduction of the C4 system into the ancestral C3 plants can minimize the amount of Rubisco and nitrogen fertilizer required and enhance water-use efficiency [16]. Nevertheless, plants without C4 evolution still undergo a highly rated selection potential for photosynthetic efficiency, nitrogen-use efficiency, and water-use efficiency with transgenic approaches [18].

Over the past four decades, studies have identified a broad range of strategic approaches to improve photosynthetic efficiency, as summarized in Table 1. These approaches are summarized into five distinct categories: (i) those focusing on a more catalytic version of RuBisCO and individual enzymes of the Calvin-Benson cycle $[19,20]$, (ii) those engineering $\mathrm{CO}_{2}$-concentration mechanisms (CCMs) into the $\mathrm{C} 3$ photosynthetic pathway [21-23], (iii) strategies required to speed up the adaptation of the photosynthetic system under natural shaded or fluctuating light conditions by increasing the quantity of the photosystem subunit [24], (iv) those engineering synthetic bypass systems for photorespiration to optimize the uptake of $\mathrm{CO}_{2}$ [25], and (v) those that correlate the swiftness in stomatal response and photosynthetic $C$ assimilation at the expense of water loss [26]. More recently, transgenic approaches have revealed that a reduction in stomatal aperture can increase WUE while enhancing $C$ assimilation or crop yields [27]. Another photosynthetic carbon-improvement approach is to ensure that photosynthesis is less affected by feedback regulation when sinks lack the potential to fully utilize all the sugars supplied by the 
source leaves. Significant progress has been made in studying the extant of sink regulations for decades; a deeper insight into how sugar is sensed and the signaling pathway will be required to activate the signaling pathway and fine-tune the feedback regulation of photosynthesis. Another alternative way of alleviating photosynthetic feedback inhibition is by increasing photosynthate transport and utilization at the sink organs, which will be discussed in subsequent sections.

\subsection{Impact of Global Warming on the Strategies to Improve Photosynthetic Carbon Assimilation}

To meet the global food production demand, crop yields of most staple crops must increase by over $60-110 \%$ in the next 30 years [28]. At the same time, atmospheric $\mathrm{CO}_{2}$ has been envisaged to reach $550 \mathrm{ppm}$ in 2050 [29], and this is usually accompanied by rising terrestrial air temperature, all in the name of global warming [30]. Today, the increasing threat of global warming is becoming more alarming, and the looming effect of these greenhouse gases can halt the positive yield prospect of our future crops. Thus, approaches to increase crop yields need to consider the future impact of global warming on crop yields. A more realistic approach to enhancing crop yields in the future is through improving photosynthetic carbon efficiency [31].

As mentioned above, various photosynthetic improvement strategies have been proposed (see Table 1), some of which have been examined under various climatic conditions, such as high atmospheric $\mathrm{CO}_{2}$ and temperature. Accelerating the rate of ribulose1,5-bisphosphate $(\mathrm{RuBP})$ regeneration $[32,33]$ is a more promising strategy to offset the predicted climatic change [32,33]. With the current ambient atmospheric condition, C3 photosynthesis is limited by the carboxylation capacity of RuBisCO. However, it has been envisaged that in the future, elevated $\mathrm{CO}_{2}$ and higher temperatures will shift the leaf photosynthesis model of carbon uptake and assimilation [34] toward the regeneration capacity of RuBisCO [35]. In case there are no other changes, a higher temperature would accelerate the activity of RuBisCO while reducing its specificity for $\mathrm{CO}_{2}$ as compared to $\mathrm{O}_{2}$. However, this will narrow the range of internal $\mathrm{CO}_{2}$ under which RuBisCO is limiting and reduce the $\mathrm{CO}_{2}$ at which RuBP regeneration becomes limiting. In principle, the positive impact of the increased capacity for RuBP regeneration (which is one of the important improvement strategies) would therefore be greatest under both rising $\mathrm{CO}_{2}$ and elevated temperature conditions. With this progress, future crops will be well adapted to the forecasted high climatic conditions (elevated $\mathrm{CO}_{2}$ and temperature).

The overexpression of the redox-regulated Calvin cycle enzyme, sedoheptulose-1,7bisphosphatase (SBPase), is another strategy used in improving photosynthesis and yield of Arabidopsis [36], tobacco [37,38], tomato [39], and wheat [40]. Based on the research progress made on these crops, Köhler et al. [41] further tested the impact of climatic change on the SBPase enzyme. They overexpressed cyanobacterial bifunctional fructose1,6/sedoheptulose-1,7-bisphosphatase (FBPase/SBPase) in soybean (Glycine max) grown in the field during three growing seasons under rising $\mathrm{CO}_{2}$ of $600 \mathrm{ppm}$ and elevated temperature of $+3.4{ }^{\circ} \mathrm{C}$. The resultant effect was further compared with normal ambient conditions (control). All the overexpressing lines had a significantly higher carbon assimilation rate across the treatments. Under ambient $\mathrm{CO}_{2}$, elevated temperature led to significant seed-yield reductions in both the control and the overexpressing genotypes. However, under elevated $\mathrm{CO}_{2}$ and increased temperature, the transgenic lines maintained higher seed-yield levels, while wild-type plants exhibited reduced seed yields compared with plants grown under elevated $\mathrm{CO}_{2}$ alone. These findings suggest that manipulating the photosynthetic carbon-reduction cycle could avert the proposed detrimental effects of future climatic change in plants. More studies should document the impact of global warming on strategies to improve carbon assimilation to ascertain future sustainability.

\subsection{Photosynthetic Carbon Assimilation Contributes to Sustainable Development Goals}

Imagine a world free of malnutrition and poverty, where people work to deliver shared prosperity in harmony with nature. This ideology moved society into declaring 
the future it wants, and the plans made were facilitated by the United Nations (UN) to launch the Sustainable Development Goals (SDGs). The UN 2030 agenda is a positive pathway to a sustainable livelihood, inclusive society, and sustainable environment. At the core of this agenda, there are 17 sustainable development goals [42], all of which must be globally achieved by the year 2030. Since photosynthesis is the underlying basis for greater crop-yield output [43], improving photosynthetic carbon assimilation is, therefore, a chief contributor to SDGs. Even though the objectives of the SDGs are intertwined, SDG 2, "end hunger, achieve food security and improved nutrition, and promote sustainable agriculture", and SDG 13, "take urgent action to combat climate change and its impacts", explicitly explain the contribution of improved carbon assimilation to achieving them.

Hunger is a global epidemic affecting underdeveloped, developing, and even developed nations. Globally, over 820 million people are severely food-insecure and malnourished [44]. In developed countries where food supply seems adequate, discrepancies in food prices add to the global hunger crisis due to increased food costs [45] and concerns of uncertainty. Furthermore, with the challenges of unemployment, high medical bills, and living expenses, millions of people are struggling to feed their families. Hence, in a bid to survive, people instead opt for cheaper undernourished foods to prevent starvation. It is imperative, therefore, to ask why the hunger crisis prevails.

Climate change plays an integral part in this global challenge, as it negates plant health, leading to drought, thereby limiting food production. Since plants have more potential to effectively resist atmospheric $\mathrm{CO}_{2}$ under ambient atmospheric $\mathrm{CO}_{2}$, increasing the number of plants will increase the absorption of atmospheric $\mathrm{CO}_{2}$. With recent research developments (Table 1), genetic engineering of $\mathrm{CO}_{2}$-concentration mechanisms (CCMs) into the plants and other strategies to improve carbon assimilation could be effective means to offset the impact of global warming on plants, ensuring food availability and sustainability. Facilitating these strategies could translate to greater yield output, consequently eradicating hunger, malnutrition, and poverty, thereby contributing directly to SDGs 1, 2, and 13 . Although several studies have been conducted on photosynthetic-improvement strategies, including the genetic-engineering approach and $\mathrm{RuBisCO}$ regeneration, research efforts should be intensified on breeding plants that can readjust to the predicted $550 \mathrm{ppm} \mathrm{CO}_{2}$ in the future. If hunger could be eradicated and the impact of global warming combated, people will have access to basic nutrition, health, education, sustainable energy, and an inclusive society, among other benefits. Importantly, the implementation of this plan starts with us. 
Table 1. Approaches employed to improve photosynthetic carbon assimilation in different plants.

\begin{tabular}{|c|c|c|c|}
\hline Host Species & Strategies & Summary of Findings & References \\
\hline $\mathrm{C} 3$ and $\mathrm{C} 4$ plants & $\begin{array}{c}\text { Modification of in vitro assay method to } \\
\text { measure the variability in carboxylase and } \\
\text { decarboxylase activity of } C_{3} \text { and } C_{4} \\
\text { leaf extract. }\end{array}$ & $\begin{array}{l}\text { RuBisCO activation status is lower in mature } \\
\mathrm{C}_{4} \text { monocot leaves than in } \mathrm{C}_{3} \text { monocots. }\end{array}$ & [19] \\
\hline Rice & $\begin{array}{l}\text { Model analysis conducted on both pot and } \\
\text { experiments under various nitrogen rates. }\end{array}$ & $\begin{array}{l}\text { Improved carboxylation rate due to higher } \\
\text { RuBisCO content in mutant plants. }\end{array}$ & {$[46]$} \\
\hline Tobacco & $\begin{array}{l}\text { Expression of zeaxanthin and violaxanthin in } \\
\text { the xanthophyll cycle coupled with an } \\
\text { increased amount of the photosystem } \\
\text { II subunit. }\end{array}$ & Greater than $15 \%$ increase in plant biomass. & {$[24]$} \\
\hline Potato & $\begin{array}{l}\text { Overexpression of pyrophosphatase in } \\
\text { mesophyll cells. }\end{array}$ & $\begin{array}{l}\text { Enhanced source and sink capacity and a } \\
\text { doubling in starch yield of tuber. }\end{array}$ & {$[47]$} \\
\hline Wheat & $\begin{array}{l}\text { Overexpression of Brachypodium distachyon } \\
\text { sedoheptulose-1,7-biphosphatase. }\end{array}$ & $\begin{array}{l}\text { Increased leaf photosynthesis, biomass, and } \\
\text { crop-yield potential. }\end{array}$ & [40] \\
\hline Tobacco & $\begin{array}{c}\text { Overexpression of Arabidopsis } \\
\text { sedoheptulose-1,7-bisphosphatase (SBPase). }\end{array}$ & $\begin{array}{c}\text { Improved photosynthetic capacity and } \\
\text { crop yield. }\end{array}$ & [38] \\
\hline Arabidopsis & $\begin{array}{c}\text { Independent or synergetic alteration of } \\
\text { sedoheptulose 1,7-bisphosphatase (SBPase), } \\
\text { glycine decarboxylase H-protein (GDC-H) } \\
\text { protein, and fructose 1,6-bisphophate } \\
\text { aldolase (FBPA). }\end{array}$ & $\begin{array}{l}\text { Enhanced carboxylation efficiency, vegetative } \\
\text { biomass, and maximal seed-yield increase. }\end{array}$ & {$[36]$} \\
\hline Potato & $\begin{array}{c}\text { Expression of polyprotein comprising three } \\
\text { subunits of Escherichia coli glycolate } \\
\text { dehydrogenase (GlcDH). }\end{array}$ & $\begin{array}{l}\text { High carbohydrate levels synthesized in the } \\
\text { source leaves were utilized by the sink organ, } \\
\text { facilitating a } 2.3 \text {-fold increase in tuber yield. }\end{array}$ & [48] \\
\hline Arabidopsis & $\begin{array}{c}\text { Expression of a synthetic, light-gated } \mathrm{K}^{+} \\
\text {channel BLINK1 in guard cells surrounding } \\
\text { stomatal pores. }\end{array}$ & $\begin{array}{l}\text { BLINK1 facilitates a } 2.2 \text {-fold increase in } \\
\text { biomass in fluctuating light without the cost } \\
\text { of water use by the plant. }\end{array}$ & [27] \\
\hline
\end{tabular}

\section{Alterations in Carbohydrate Partitioning When Manipulating Photosynthesis Affect Plant Growth}

Crop yields depend on photo-assimilates synthesized through photosynthesis (source capacity) and their utilization at the sink organ. Thus, experimental manipulations of source activity and sink strength explain the strong coordination between carbohydrate utilization at the sink level and photosynthesis. Photosynthetic products are primarily translocated to the sink organ in the form of sucrose (synthesized at the source leaves) for sink growth development. Thus, any activity that improves photosynthesis could also increase plant growth. In most cases, low sink activity resulting from sink removal or the integration of nutrient deficiency enhances carbohydrate accumulation in source leaves, and photosynthesis becomes downregulated [49,50]. A decline in photosynthesis could also occur when sucrose export from the source leaves to the sink organs becomes inhibited due to the downregulation of sucrose transporter genes [51]. In both cases of decreased sink activity or restrictions in sucrose transport, sucrose accumulates at the source leaves, increasing the expression of genes involved in carbohydrate storage and utilization, while repressing photosynthetic genes expression and final plant growth [52]. However, increases in sink demand have also been reported to improve photosynthetic activity and sink growth [53,54]. For example, $50 \%$ of blueberry plants were defoliated due to increased sink demand, but high photosynthetic capacity and yield were maintained [54]. Kaschuk et al. [53] have also shown that increased sink demand due to $\mathrm{N}_{2}$ fixation in soybean (Glycine max) relative to the nitrate-fed plants underpinned the observed increase in photosynthetic capacity and delayed leaf senescence. As such, plant breeders aiming at improving crop yield should be cognizant of the fruit pool size and photo-assimilate delivery from source leaves to sink organs (fruits). 
The growth of plants at elevated $\mathrm{CO}_{2}$, which alters source supply, has revealed the strong association between source photosynthesis and sink demand. In most C3 plants, elevated $\mathrm{CO}_{2}$ directly enhances photosynthesis, which has led to increased carbohydrate supply in leaves, and an ultimate increase in crop yields [55]. Previous studies have shown that photosynthetic stimulation by elevated $\mathrm{CO}_{2}$ may be limited by the sink's capacity to utilize or store additional photosynthates in $\mathrm{C} 3$ plants [56]. The initial increase in the photosynthetic rate was then greatly reduced by the suppression of photosynthetic activity due to the negative feedback caused by limited sink capacity. This is an indication of photosynthetic limitation by the sink after the initial limitation of carbon partitioning and growth by the source activity. Subsequent findings have revealed that the degree of photosynthetic stimulation by the interacting elevated $\mathrm{CO}_{2}$ and environmental, experimental, or genetic factors determines the sink strength $[57,58]$. For example, faba beans grown under an elevated $\mathrm{CO}_{2}(700 \mathrm{ppm})$ environment and exposed to well-watered versus drought treatments exhibited increased photosynthate accumulation in the leaves, leading to feedback inhibition of photosynthesis [58]. Similarly, poplar (Populus spp.) trees, which export more than $90 \%$ of photosynthate during the day, maintain high stimulation of photosynthesis at elevated $\mathrm{CO}_{2}$ [59]. Thus, maintaining the photosynthetic stimulation at elevated $\mathrm{CO}_{2}$ could be strongly associated with the capacity of the sink organ to utilize or reserve the additional carbohydrate [57,58].

Synthesis and degradation of starch is also a clear indication of carbon supply and utilization, especially in Arabidopsis [52,60]. The fixed carbon obtained during photosynthesis could be converted to sucrose (usually stored in the cytosol) and starch (majorly stored within the chloroplast of most plants) in the source leaves. In most plants, source leaves (older leaves) majorly export all the fixed carbon to sink leaves and other reproductive parts of plants for growth and other metabolic activities. Plants accumulate starch more rapidly during the day and degrade it at night to support growth and metabolism. The leftover starch is reserved until dawn. The rate of starch synthesis and degradation across a range of photoperiods is adjusted to avoid carbon starvation [60,61]. Weraduwage et al. [62] reasoned that the optimal partitioning of carbon to starch would occur when the carbon available for growth was constant day and night. As such, the budgeted carbon for growth should be the same during the day and at night because all the energy from growth is majorly attributed to this fixed carbon [61]. The growth derived for carbon usage may be more efficient than that obtained at night if ATP can directly optimize growth. On the other hand, the carbon budget for growth at night could also be greater than that during the day because sucrose synthesized during the day requires one ATP plus the energy demand in the tricarboxylic cycle. However, carbon primarily stored as starch and then transformed to sucrose requires one and two-thirds (assuming two-thirds of the nighttime export is maltose and one-third is glucose) [62]. Thus, the photosynthetic products are strictly adjusted based on the plants' demand. Interestingly, increase in starch content at the end of the light period (which supports carbon metabolism and growth at night) decreased with biomass accumulation across 94 Arabidopsis accessions [63]. This indicates that plants with a strong affinity for starch accumulation exhibit reduced growth, while plants with improved growth rates incur better carbon-use efficiency, re-emphasizing the relationship between photosynthetic machinery and plant growth.

\section{Transport of Sucrose to the Sink}

The need for a high $C$ assimilation rate elucidated above can only be effective if the increased C supply can be utilized by downstream transport and plant metabolic processes. Thus, all photo-assimilates not required for leaf function are turned into sucrose or amino acids and translocated to the sink organ via the phloem [2]. Up to $80 \%$ of photosynthetically fixed carbon can be exported from mature leaves. However, the quantity of sucrose available for export from source leaves anchors on factors including photosynthetic activity (primarily the carbon-fixation), partitioning between the starch synthesis within the chloroplast and triose-phosphates moved out of chloroplast for sucrose synthesis, and 
temporary accumulation of sucrose in the vacuole [64]. The synthesized sucrose is then exported to various plant organs depending on demand, while other redundant sucrose is converted into starch and stored for further utilization. Alteration in any of these aforementioned factors can affect the quantity of sucrose available for export, thereby changing the source-sink balance [64].

Photo-assimilate transport comprises short-distance (e.g., loading/unloading of sucrose) and long-distance transport [65]. Phloem cells that convey organic materials and sugars within the plant are called sieve elements. The known mechanisms of active phloem loading presently are: (i) symplasmic loading, where de novo-synthesized sucrose has to exit the mesophyll cells and transfer from cell to cell via plasmodesmata (PD) (which acts as the bridge across the cell walls) into the sieve elements (Figure 2); (ii) apoplastic loading; which involves the movement of sucrose from mesophyll cells to companion cells against a concentration gradient (Figure 2); and (iii) "polymer trapping", which involves the conversion of sucrose into larger sugar polymers such as stachyose, verbascose or raffinose symplasmically supplied by intermediate cells $[64,66]$. All these aforementioned pathways follow the three phloem sections (collection, transport, and release phloem) to effectively unload sucrose at the sink organ. These entail sucrose loading into the collection phloem (embedded at the leaf blade) [67], which signifies the first step of long-distance transport (Figure 2). The subsequent step is the transport of sucrose via the transport phloem (path of sucrose transport) connecting the source leaves with sink organs, and then the final delivery of sucrose via the release phloem to the sink organs (Figure 2) [64,67].

In various loading-pathway routes, specific transporters are needed to efficiently transport sucrose across plasma or within the intracellular compartment. Thus, these sucrose transporters serve as significant regulators of sugar flux and accumulation [68,69]. These transporters are localized in the three phloem sections, and their function cannot be underestimated, especially in tree crops where sucrose loading is symplastic in the collection phloem [70,71]. Nevertheless, sucrose is removed from the phloem via either a symplastic or an apoplastic pathway in the release phloem, albeit the preliminary steps are often symplastic [72]. Thus, disruption in the symplastic pathways in sink organs like developing seeds requires an apoplastic step to efficiently transport photo-assimilates. It is noteworthy to mention that regulating these sucrose transporter genes significantly improve crop yields [69]. A good example is the sucrose transporter (OsSUT2), which functions in the transport of sucrose from the vacuole across the tonoplast. Disruption in the function of the OSSUT2 transporter restrains sugar transport basipetally from source leaves to sink organs; thus causing major physiological disorder and rice yield loss [73]. This indicates the crucial roles of sucrose transporters displayed in phloem loading and unloading at the sink organ. During the early stages of the tuber developmental stage in potato, tuber-specific inhibition of SUT1 reduces the fresh weight, demonstrating the potential role of SUT1 in phloem unloading [9]. More research attention have been directed towards a new class of sugar transporters, Sugars Will Eventually be Exported Transporters (SWEETs), in Arabidopsis AtSWEET10-15 [74], and rice OsSWEET 11 and 14 [75] which are responsible for sucrose export from the transport phloem to the apoplast. The Arabidopsis double mutant, atsweet 11 or 12, exhibits impaired ability to expunge sucrose out of the leaves. This inhibition resulting from starch accumulation leads to downregulation of photosynthesis, demonstrating that sucrose export by the SWEET family plays an imperative role in photosynthetic improvement. Sucrose unloaded into the apoplastic space is assimilated by the sink cells or bonded by invertase to hexose transported by specific carriers (Figure 2). As such, sucrose can either be stored for sink growth and development or left in the vacuole of the storage cells of some crop species, such as sugar cane and sugar beet [76]. 


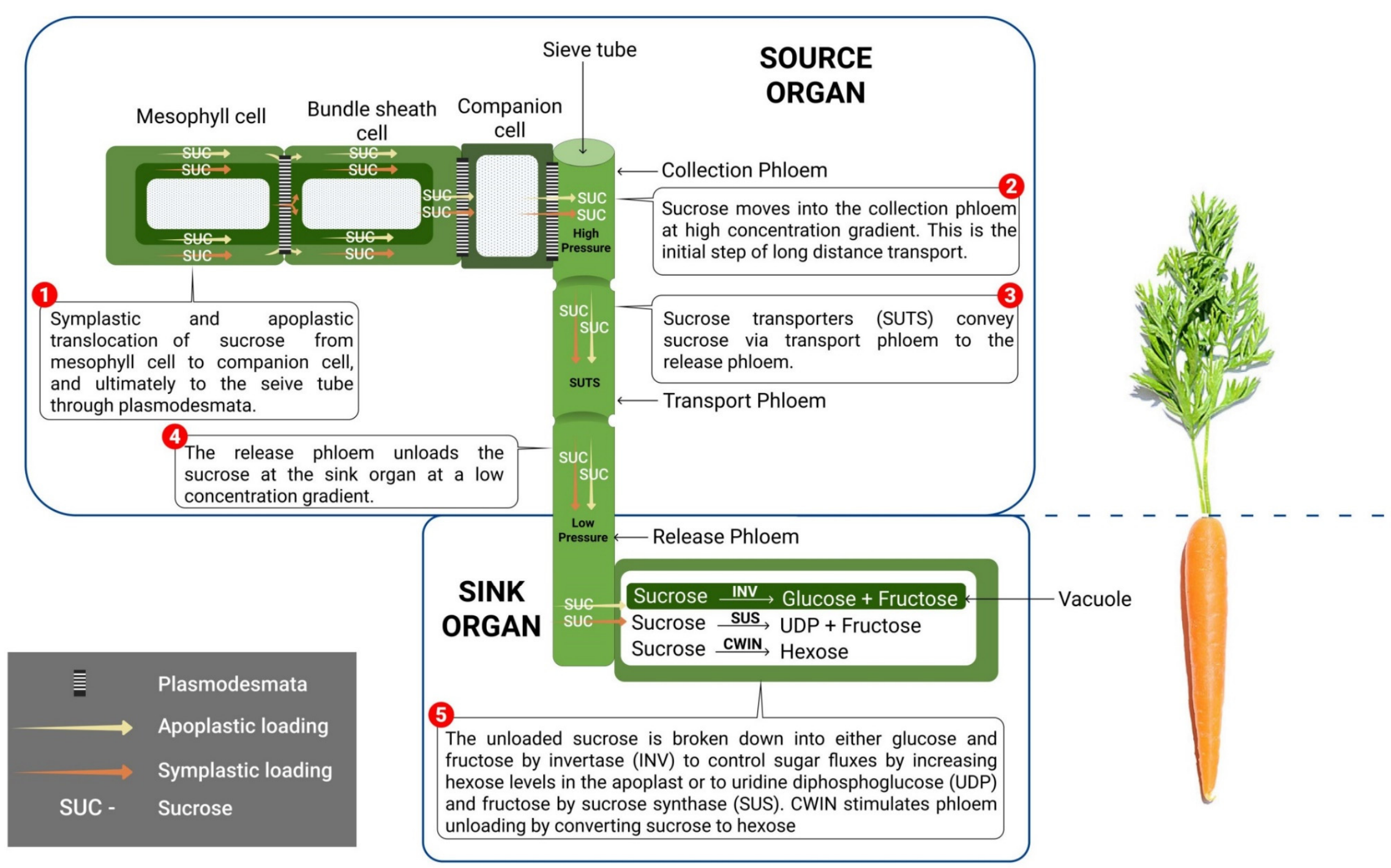

Figure 2. Schematic diagram of symplastic and apoplastic transport of sugar from source to sink organ. 


\section{Sucrose Utilization at the Sink}

Photo-assimilates are symplasmically unloaded from the phloem through plasmodesmata (PD), which serves as a bridge connecting the surrounding cells to sink organs [68]. The sucrose delivery by the release phloem (Figure 2) improves physiological growth of sink organs. The homogenous distribution of assimilates within the sinks is a major driver of plant productivity, and it is expressed as the harvest index (HI). The $\mathrm{HI}$ is calculated as the proportion of harvested dry weight divided by overall plant dry weight or above-ground dry weight. Thus, plants with high $\mathrm{HI}$ have a greater percentage of its photo-assimilates diverted back to the sink [64].

There exist fluctuations in carbon partitioning and shifts between the symplastic and apoplastic pathways throughout plant developmental processes. The pathway through which sucrose is unloaded depends on the specific sink involved and its developmental stages $[77,78]$. For example, sucrose unloading is apoplastic during the fruit developmental stage in apple [79]. In potato [80] and white mature jujube [77], the mode of phloem unloading transits from apoplastic to symplastic. Contrary to this, sucrose unloading is symplastic during the early and middle stages of grapefruit development, but subsequently switches to apoplastic during the fruiting stage [81]. The switch to a symplasmic unloading pathway route is mainly based on the amount of plasmodesmata [77], an indication that symplasmic unloading strongly exceeds the transport capacity of the apoplastic pathway. At the sink level, sucrose is broken down into glucose and fructose by invertase (INV) [82] to control sugar fluxes by increasing apoplasmic levels of hexoses in the apoplast (Figure 2). Sucrose can also be degraded into uridine diphosphoglucose (UDPG) and fructose by sucrose synthase (SUS), albeit the energy demand for degradation is higher in INV than SUS. INV is encoded in cell-wall invertase (CWIN), which plays an imperative role in apoplasmic phloem unloading in sink organs. CWIN-derived glucose predominates the sink tissues to trigger cell division during early seed development, whereas sucrose synthase synthesizes starch, cellulose, and protein during the late developmental stages for sink strength $[83,84]$. Cell-wall invertase also increases sucrose unloading to the sink organ by converting sucrose to hexoses (Figure 2). Since plants are highly susceptible to sucrose imbalance in the sink organ, promoting the activity of endogenous CWIN by silencing its inhibitor is a potential molecular strategy to lessen the effect of sink abortion.

\section{Influence of Environmental Factors on Photo-Assimilate Transport}

Plants undergo a wide range of environmental changes all through their life-cycle, and have evolved diverse strategies to withstand such changes. The impact of environmental factors on photo-assimilate transport within the source and sink is discussed in the subsequent sections.

\subsection{Effects of Carbon Dioxide}

Nowadays, the atmospheric concentration of carbon dioxide $\left(\mathrm{CO}_{2}\right)$ is approximately twice that which prevailed over the past few centuries [1] due to the impact of fossil combustion and inappropriate use of agricultural lands. Indeed, the concentration of $\mathrm{CO}_{2}$ in the atmosphere increased from approximately $315 \mathrm{ppm}$ a few decades ago to an average of $390 \mathrm{ppm}$ in these present days. The concentration has been envisaged to be within the range of 540 to $970 \mathrm{ppm}$ before the end of the century. Despite the pressure imposed by this increased atmospheric $\mathrm{CO}_{2}$ on the global climate, its impact on plant photosynthesis cannot be underestimated. A rise in $\mathrm{CO}_{2}$ could promote photosynthetic rates and carbohydrate production, and positively affect phloem transport and growth. However, these factors depend on either the short- or long-term $\mathrm{CO}_{2}$ enrichment terms. Most plants subjected to short-term $\mathrm{CO}_{2}$ treatment effectively accumulate carbohydrates in the leaves, increasing biomass partitioning between their source and sink organs (Figure 3). However, prolonged exposure (long-term effects) of some other plant species to elevated $\mathrm{CO}_{2}$ concentration reduces the initial stimulation of photosynthesis and decreases the photosynthetic rate [85]. For example, an increase in the $\mathrm{CO}_{2}$ concentration of soybean plants subjected to 27 days of 
treatment from 400 to 1000 ppm resulted in a drastic reduction in photosynthetic rate [86,87], which subsequently affected the crop yield. This reduced net photosynthetic rate may be due to the reduced concentration and activity of RuBisCO [88] or the source-sink imbalance emanating from leaf carbohydrate accumulation under increased $\mathrm{CO}_{2}$ concentration [89]. This reduction in the net photosynthetic rate observed during long-term exposure could also be advantageous, as it potentially enhances the remobilization of assimilates from the source leaves to the sink for proper readjustment of the source-sink balance [90].

SOURCE ORGAN

Short-term $\mathrm{CO}_{2}$ treatment effectively accumulates sucrose in the source leaves.

Sucrose accumulation in a flag-leaf decreases the Triose Phosphate Utilization (TPU)

Under dark or shaded condition, carbon previously stored in the cotyledon are used up for hypocotyl elongation to promote root over shoot growth.

Starch accumulated is slowly degraded at night while preeserving others till dawn.

T Reduction of tricarbonxylic acid cycle under high night temperature.

T High temperature reduces photosynthetic rate since photosynthesis is high temp-dependent.

T Disruption of Rubisco activity.

D More storage of soluble sugars in source leaves.

D Disrupts sucrose synthensis and inhibits sucrose partitioning

N Nutrient imbalance affects photosynthetic activity, carbohydrate accumulation in the leaves and root.

N N and P deficiency decreases photosynthetic rate due to reduction in Rubisco act.

\section{Effects of carbon-dioxide \\ Effects of light \\ T Effects of temperature \\ D Effects of drought \\ (N) Effects of nutrient availability}

SINK ORGAN

Growth inhibition under high temperature.

D Low demand for sucrose at the sink organ.

D Retarded fruit growth due to source and since limitation.

N Nutrient imbalance alters the shoot-root biomass ratio.

N Nutrient imbalance results in stunted growth and severe yield loss

Figure 3. The impact of environmental factors on photo-assimilate transport.

Source-sink imbalance is mostly apparent during plant exposure to elevated $\mathrm{CO}_{2}$, when photosynthetic rate outweighs the transport capacity or the capacity of sinks to utilize assimilates for growth. This incapability results in carbohydrate accumulation in photosynthetically source leaves [90]. Contrary to this opinion, CAM plant Opuntia ficusindica exposed to long-term high $\mathrm{CO}_{2}$ concentration was not affected by the photosynthetic rate [91]. In fact, after three months of subjecting the plant to double $\mathrm{CO}_{2}$ concentration of $750 \mathrm{~mol} / \mathrm{mol}$, the glucose, starch, and malate contents in the basal cladodes increased significantly compared with the low $\mathrm{CO}_{2}$ concentration of $370 \mathrm{~mol} / \mathrm{mol}$; however, the sucrose content was not affected [91]. The sucrose content in mother cladodes was not affected because it was translocated to daughter cladodes by an active phloem transport, thereby resulting in a marked increase in the biomass of daughter cladode after three months of exposure to high $\mathrm{CO}_{2}$ concentration [87,91]. The impacts of elevated $\mathrm{CO}_{2}$ on photosynthetic carbon assimilation are not the same, since some plant species are easily affected by elevated $\mathrm{CO}_{2}$ than other plant species. Thus, variations in plant species response to elevated $\mathrm{CO}_{2}$ are mainly engendered by diverse plant photosynthetic types.

Triose phosphate utilization (TPU) explains the response of photosynthesis to carbon source-sink imbalances at elevated $\mathrm{CO}_{2}$. Although several studies have shown that elevated $\mathrm{CO}_{2}$ treatment [92-95], experimental manipulation (pruning) of source-sink carbon $[96,97]$, or a synergetic impact of both can influence source-sink balance [98,99], more exciting advances have recently emerged. Fabre et al. [100] explored the impact of sourcesink imbalances on photosynthesis, which is best predicted by the limitation of triose 
phosphate utilization. They also investigated the response of TPU on photosynthetic regulation under such imbalances. The group hypothesized that there is a linear relationship between the source-sink ratio and TPU limitation in rice leaves. To test this hypothesis, they subjected rice plant to elevated $\mathrm{CO}_{2}$ in order to achieve increased source capacity, and also pruned the panicle (sink) to decrease the sink. They observed a genuine association between the source-sink balance and TPU capacity. There was a negative correlation between TPU capacity and the flag-leaf sucrose concentration (increase in sucrose decreases the TPU), and a linear correlation between TPU and photosynthesis (photosynthesis decreased during the day along with TPU) (Figure 3). This reduction in TPU is associated with the accumulation of sucrose in the flag-leaf resulting from sink limitation. As such, TPU could be adjusted to be slightly higher than the photosynthetic rate or vice versa, albeit the case might be different in plants whose sink adjustment and assimilate transport to increased assimilation potential is poor.

\subsection{Effects of Light}

Light is one of the most paramount factors affecting shoot and root development during early seedling development [101]. Energy derived from light facilitates carbohydrate synthesis during photosynthesis. When seedlings are kept in the dark or shaded from light at the early germination stage, a larger quota of the $C$ assimilate previously stored in the cotyledons are used up for hypocotyl elongation (Figure 3), inhibiting the root growth. Growing seedlings under the shade with a low ratio of red to far-red light induces hypocotyl elongation to promote shoot over root growth (Figure 3) [101]. This occurrence moves cotyledons, as well as the shoot apex, toward the light. Subsequently, the de-etiolated seedling begins photosynthesizing to produce sucrose, since the delivery of assimilate to the root is subject to changes in sucrose availability. Studies have revealed that photosynthetic transport of sucrose from the shoot (cotyledon) to the root functions as a direct signal to activate and enhance root elongation of Arabidopsis in a light-dependent manner [4]. This finding and other related findings [102,103] support the efficacy of carbon resources in coordinating long-distance transport in the presence of light, as the illumination of shoot promotes root growth via shoot-to-root signaling.

To cope with nights characterized by lack of sunlight and prevailing darkness, plants devised a coping strategy similar to that of a battery. During the day, a portion of plant photosynthates is allocated for storage in the form of starch. At night, in the absence of light and photosynthesis, these stored resources are reallocated to sustain plant growth and metabolism (Figure 3) [104,105]. Starch degradation at night clearly explains the carbon economy of the plant, as well as plant growth. Starch degradation, carbon availability, and growth at night progressively decrease as the photoperiod becomes shortened [60]. Plant growth rate anchors majorly on the amount of starch available at dusk and the length of the dark periods $[60,106]$. In short photoperiods, starch is mostly exhausted at dusk due to carbon limitation in plants during this period, causing severe growth inhibition [107-109]. If the duration of the night is suddenly extended, starch will be completely consumed within 1 to $2 \mathrm{~h}$, the amount of sucrose becomes drastically reduced, catabolism will be activated, and ultimately growth becomes inhibited. As such, proper coordination of starch degradation and growth is an expedient to preventing either the accumulation of sugar or its depletion to a point where catabolism is activated. This coordination could be obtainable if: (1) the circadian clock acts directly to regulate plant growth rate and timing, and (2) the coordination could also occur through an indirect action of the clock by regulating the rate of starch degradation and determining the amount of sucrose available for growth [109]. Unlike the short photoperiod, during which growth decreases in the early hours of the day, plants subjected to longer photoperiods exhibit increased growth during the night and at the start of the day. There is a more pronounced lag before starch accumulation commences again [60]. The delay in starch accumulation is mostly accompanied by increased sucrose synthesis and other soluble metabolites, indicating that growth is not carbon-limited. Future research should focus on the cause of this delay; this 
could have been due to limitations arising from starch accumulation or introduction of degraded starch towards the end of the light period.

Light also regulates phloem loading of sucrose from the photosynthesizing leaves, either "apoplastically" or "symplastically" [110,111]. Apoplastic loaders (pea and spinach) and symplastic loaders (pumpkin and Verbascum phoeniceum) acclimatize to photosynthesis differentially in response to light environment. Thus, increased cell-wall invagination, indicating no greater starch levels, was observed in the leaves of apoplastic loaders transferred from low to high light condition [112]. However, in symplastic loaders, there was no increase in the plasmodesmatal frequencies per loading cell, thereby accumulating sugar in the source leaves $[112,113]$. This modification is consistent with the limitation in carbon export capacity to increase plasmodesmata density in mature leaves.

\subsection{Effects of Temperature}

Extremes of temperature are harmful to plant health. Thus, maintaining a favorable leaf temperature is essential for plant growth because photosynthesis can be maximized within a relatively narrow temperature range [1]. Most biochemical reactions of photosynthesis are disrupted (Figure 3), since photosynthesis is a temperature-dependent process [114]. Temperature also affects the membrane integrity of the chloroplast [1] and irreversibly disrupts RuBisCO activity (Figure 3) [115]. Recently, cocoa seedlings subjected to an elevated temperature of approximately $39{ }^{\circ} \mathrm{C}$ heat treatment against $36{ }^{\circ} \mathrm{C}$ in chamber control were negatively affected by the photosynthetic rate and biomass accumulation [116]. In addition, wheat plants subjected to heat stress also exhibited disruption in floret settings, resulting from limitation in photo-assimilate supply at the source leaves and varying photoperiodic sensitivity [117]. This implies that photo-assimilate supply and the quantity of reserved assimilate stored in the vegetative tissue are key determinants of floret formation and subsequent grain (sink) development under heat stress $[118,119]$. Although ample evidence exists regarding the negative impact of heat stress on crop yields [120-122], little is known about the source-sink metabolite dynamics and crop-yield interaction [123]. More recently, Impa et al. [124] examined the metabolic changes in six winter wheat genotypes by investigating the post-heading high night temperature (HNT) effect on carbon balance, sink-source metabolic changes, and other yield-related traits relative to the control experiment (at $15{ }^{\circ} \mathrm{C}$ minimum night temperature). In the same study, a marked increase in proteinogenic amino acids and carbohydrates, such as sucrose, glucose, fructose, and raffinose, was detected in the spikes (sinks) during HNT relative to the control condition. However, a drastic reduction of the tricarboxylic acid cycle intermediate compounds was found in the source leaves (Figure 3). To this end, changes in carbohydrate metabolism and tricarboxylic acid cycle intermediate in the spikes and leaves provide insight into metabolites involved in HNT response [124]. Wang et al. [125] investigated the effects of heat stress on 38 wheat varieties (with different levels of thermo-tolerance) to unravel the proteomic and metabolomic changes induced by this stress during the grain-filling stage. They observed a marked increase in the free amino acid levels and a drastic reduction in the content of carbohydrate metabolism and tricarboxylic acid (TCA)-related metabolite in response to heat stress. This result suggested a plausible wide range of mechanism for heatadaptive metabolism required to maintain the grain-filling process in plants [125]. Plant breeders should focus on the integration of this metabolomic and other omic approaches; this could provide an insight into the appropriate markers that can be used to address the issue of climate change in this century.

Low temperature also poses a major threat to sugar transport within different cell types (intermediary cells, parenchyma transfer cells, sieve elements) in diverse manners. Plants with a symplastic minor-vein configuration seem to be dominant in tropical and sub-tropical regions, whereas plant species with an apoplastic configuration are mostly found in temperate zones. Hence, one would believe that the symplastic loaders can be more cold-sensitive than apoplastic loaders [64]. The sensitivity of herbaceous species and deciduous trees with symplastic phloem-loading to cold was due to the collapse of 
intermediary cells under low temperatures, eliminating photo-assimilate transport and starch accumulation in the chloroplast [113]. These ultrastructural changes have also been found in broad leaf evergreen species (Ajugareptans, Aucubajaponica, and Hederahelix) that have a symplastic phloem-loading mode. At low temperature, leaves of this latter plant exhibit a higher exudation rate, but neither shows any symptoms of frost injury nor starch accumulation in the chloroplasts. Therefore, removing redundant photo-assimilates from cold-acclimated source leaves might be crucial to maintaining the functional and structural integrity of the plant [126]. However, physiological studies [127] showed no significant variation between symplastically and apoplastically phloem-loading species in response to cold, since the carbohydrate available for export in phloem-loading modes of both species was closely related. This has led to the hypothesis that there is a relationship between the phloem-loading mode and the growth architecture instead of the geographical distribution of both species.

Although low temperature drastically reduces plant growth rate and final biomass, even in plants well acclimated to low-temperature regimes, some geophytes still exhibit increased growth rate and a much larger storage organ under such a temperature regime [128]. This observed positive growth effect in storage organs was correlated with enhanced leaf longevity and extensive periods of carbon assimilation, which is partly related to improved biomass in the storage organ [128]. In the same study [128], higher temperatures halted corm (sink) growth (Figure 3) even before the first visual signs of leaf senescence became apparent, suggesting the great influence of sink activity on leaf longevity in spring ephemerals (Crocus vernus). As such, leaf senescence is induced by sink limitation once the carbohydrate reserves are replenished [129]. It can be inferred that the larger storage organs could have resulted from increased overall sink strength at low temperature gradients in these species. The production of a larger storage organ under a lower-growth temperature regime $\left(8 / 6^{\circ} \mathrm{C}\right)$ was also affirmed in Erythronium americanum. The increased growth rate observed at lower temperature gradients could be attributed to the delay in starch accumulation, leading to improved source-sink balance and delayed leaf senescence [130].

\subsection{Effects of Drought}

Considerable proportions of our global agricultural lands are prone to drought. Drought has been extensively reported to directly facilitate a wide range of yield-reduction symptoms in plants. These symptoms include photosynthetic inhibition [131], physiological metabolic disorders [132], and increased oxidative stress [133]. In a bid to survive, plants have evolved a series of morphological and physiological adaptive mechanisms to withstand a water-deficit condition [134]. When a plant root directly senses a water deficit, the biomass allocated to the root increases over that allocated to the shoot, facilitating increased root-over-shoot growth in rice [134,135], Arabidopsis thaliana [136], wheat [137], and soybean [138]. This case of plants' response to drought is an indication that a higher root-to-shoot ratio could be an adaptive parameter to improve plants' tolerance to drought stress [139]. Hence, maintaining an efficient root (sink) system is a precursor to increasing water uptake while preventing water loss in response to drought stress.

Excessive transpiration disrupts the synthesis of photosynthetic products (Figure 3), inhibits carbon utilization at different sink tissues [113]. Most research has documented that most drought-induced sugar metabolism and phloem loading alters carbohydrate levels in leaves at different plant developmental stages $[140,141]$. Plants subjected to drought stress usually have accumulated soluble sugars, including sucrose, stored in their source leaves (Figure 3). The accumulation of this stored sucrose in the source leaves act as an imperative energy derivative strategy which improves plant tolerance to drought stress condition [142]. Interestingly, sucrose could also be accumulated in the leaves if there is a low demand for sucrose at the sink cell [136]. Thus, sucrose accumulation in the leaves could be drought-induced or result from low-sink demand (Figure 3).

Drought stress also stimulates leaf senescence and enhances reserve remobilization, since these play an integral role in plant development and other fundamental strategies re- 
quired for stress mitigation $[143,144]$. The concentration of sugar can also influence leaf development, with senescence being the fundamental causal signal and the primary substrate responsible for carbon remobilization to alleviate the drought-stress effect [145]. Transgenic tomato plants overexpressing Arabidopsis hexokinase (HXK) exhibit increased sugar contents, which suppresses photosynthetic activity and increases leaf senescence [146]. Meanwhile, drought-induced leaf senescence promotes the redistribution of assimilates to developing grains and increases rice grain-filling rate [147]. For instance, water deficit during grain-filling decreases seed size in soybean due to the reduction in the period of grain-filling [148,149]. Seed growth anchors majorly on the amount of assimilate supplied from the maternal plant (source activity) and the assimilate demand within the embryonic tissues (sink activity), indicating the pivotal role of both source and sink activity in enhancing seed growth under a drought condition. Thus, Westgate et al. [148] hypothesized that a rapid reduction of sucrose within the embryo depicts source limitation, whereas a delay in sucrose uptake connotes sink limitation. Despite the reduction in sucrose concentration caused by water deficit, the dry weight of the seed increases at or close to the control rate, thereby triggering the remobilization of reserve carbohydrates from all source organs to improve seed growth [148]. Drought could also impede fruit growth and development caused by both sink and source limitations (Figure 3) [150]. A well-ripened grape berry under drought is an excellent example of a sugar sink that exhibits a great yield reduction while increasing the total sugar content of the remaining berries [64]. The most droughtsensitive stage is the early developmental stage of grape berry; however, drought has no effect on sugar accumulation at this stage. This is an indication that sink strength within each of these berries is determined majorly by sink activity, rather than the berry size resulting from sugar accumulation [151]. For efficient crop-yield improvement, an in-depth understanding of the effect of drought on sugar accumulation at that early developmental stage (crucial stage) is required.

\subsection{Effects of Nutrient Availability}

Humans respond to nutrient deficiency, becoming malnourished under such conditions. Plants are not left out of this; any shortage in nutrient supply can dramatically affect resource allocation, resulting in stunted growth and severe yield loss (Figure 3). The effects of nutrient starvation on long-distance transport and assimilate allocation within plant tissues have been extensively studied [152]. Hu et al. [153] suggested that nutrient starvation can greatly influence the distribution of photo-assimilates directly through phloem loading and transport, or indirectly by reducing sink demand. Hossain et al. [154] also reported that the supply or deprivation of macronutrients affects the root-to-shoot partitioning of dry matter, especially in higher plants. All these findings point toward the imperative role of mineral nutrients in biomass reallocation and crop-yield improvement. Nutrient imbalance affects photosynthetic activity and carbohydrate accumulation in the leaves and root, and alters the shoot-to-root biomass ratio (Figure 3).

The efficient use of nitrogen $(\mathrm{N})$ has been a bottleneck affecting global agricultural systems. N deficiency drastically reduces the photosynthetic rate, the number of flowers, and crop yields due to the decrease in the amount of RuBisCO protein and activity $[155,156]$. Roots subjected to $\mathrm{N}$ deficiency accumulate more photosynthetic products such as sucrose and sorbitol. Thus, unloading of photosynthates to the roots primarily serves as an energy source and signal molecule involved in root growth, thereby increasing the root-to-shoot biomass ratio [155]. Increased root carbon boosts the chances of the root to forage for more $\mathrm{N}$ in the soil or nutrient solution, indicating the relationship between the signaling roles of sugar and nitrate $\left(\mathrm{NO}_{3}{ }^{-}\right)$in improving shoot and root growth. However, plants subjected to low $\mathrm{N}$ concentration exhibit a reduced growth rate due to shortage in the supply of amino acid pool needed to sustain protein synthesis essential for the formation of new tissues. As such, the starch content in the leaves increases significantly. However, the mechanism behind this sugar accumulation in response to the deficit is yet to be clarified. Taken 
together, $\mathrm{N}$-deficiency could result in biomass reduction, starch accumulation in the leaves, and greater carbon reallocation to the root, leading to increased root-over-shoot growth.

On the other hand, excessive $\mathrm{N}$ supply is mainly characterized by a wide range of ammonium $\left(\mathrm{NH}_{4}{ }^{+}\right)$toxicity symptoms, including ion imbalance, leaf chlorosis, $\mathrm{pH}$ regulation disorder, and physiological metabolic disorder [157]. The excessive $\mathrm{N}$-replete also affects the net carbon assimilation rate via its effects on the photosynthetic component [158]. Studies have also reported that excessive $\mathrm{N}$ supply reduces the root carbon by diverting unassimilated $\mathrm{NO}_{3}{ }^{-}$acropetally back to the shoot via xylem to promote shoot development, thus retaining more photosynthetic carbon in the shoot $[159,160]$. The development in the shoot organ only stimulates vegetative growth, reducing the number of flowers and fruit yield. This suggests that a balanced distribution of sucrose between the source leaves and flowers might act as major yield-determinant factors [158], since the flowering process depends on sucrose supply. In contrast to the findings regarding lower root:shoot ratio, a higher root:shoot ratio was observed under excessive $\mathrm{NH}_{4}{ }^{+}$compared with $\mathrm{NO}_{3}{ }^{-}$in tobacco [161] and cucumber [162]. The shift in biomass partitioning favoring the root implied accelerated phloem transport of assimilates to the root under $\mathrm{NH}_{4}{ }^{+}$nutrition. The dynamic changes in root:shoot biomass ratio observed in most of these plant species resulted from the alteration in carbon partitioning between the root and shoot when different $\mathrm{N}$ rates were applied.

Besides nitrogen, phosphorus $(\mathrm{P})$ is the second macronutrient required for plant growth and yield. P deficit directly affects photosynthesis due to the inorganic phosphate (Pi) availability in the chloroplast, resulting in reduced carbon assimilation in the leaves. Similar to $\mathrm{N}$ deficiency, phosphorus limitation induces carbohydrate accumulation, increasing the root:shoot ratio. Sucrose transport across the phloem is often stable and sometimes increases during the early phosphorus-deficit phases [163]. The significance of sucrose transport in P-deficiency signaling has been clearly demonstrated in white lupin [164]. Liu and colleagues argued that the expression of white lupin phosphate transporter, LaPTI, and a secreted acid phosphatase gene, LaSAP1, responsible for phosphate acquisition, is rapidly induced by phosphate deficit. Phosphate-deficient plants were then treated by stem-girdling to hinder shoot-root sucrose transport, but no induction of either LaPT1 or LaSAP was observed. As such, the amount of sucrose in the leaf translocated to the roots was reduced by $95 \%$ in stem-girdled plants, indicating the importance of sucrose transport in plants subjected to phosphate-starved condition. However, the response of nitrogen $(\mathrm{N})$ and phosphorus $(\mathrm{P})$ deficiency seems similar due to the starch accumulation in the leaves and carbon sequestration in the root, increasing the root-to-shoot biomass ratio. However, $\mathrm{N}$ and $\mathrm{P}$ limitations are shaped differently in response to plant growth, since both macronutrients perform different functions in the machinery of plant energy metabolism, photosynthesis, and respiration [165].

Potassium $\left(\mathrm{K}^{+}\right)$is another macronutrient whose availability also affects the sourceto-sink relationship. Potassium deficiency reduces the photosynthetic rate and plant growth due to the sucrose sequestration in the leaves [166,167]. One would think that increased sugar concentration in the leaves could enhance root sugar content; instead, root sugar and growth are disrupted, since sugar translocation is halted due to higher sugar content in the leaves. Hence, sucrose and starch concentrations in K-depleted plant roots are significantly reduced compared with the K-repleted counterpart [166]. A good explanation for this is that the reduction in sucrose exported to the K-deficient root is attributed to the changes in the concentration of $\mathrm{K}^{+}$, which could affect phloem-loading of sucrose [168]. A member of Arabidopsis potassium-transporter family, AKT2/3, has been identified as the photosynthate-induced phloem potassium channel, which affects sucroseloading and long-distance transport by regulating the activity of sucrose $/ \mathrm{H}^{+}$symporter via the phloem potential $[169,170]$. The authors revealed that a significant fraction of net photosynthetic $\mathrm{CO}_{2}$ leaking out of sieve tubes seemed not to be effectively loaded (retrieval) into the phloem of the mutant. Hence, akt2/3 exhibits a drastic reduction in the amount 
of sucrose in the phloem sap. These scenarios reduce the root-over-shoot biomass ratio of K-depleted plants.

Studies have also reported the influence of magnesium $\left(\mathrm{Mg}^{2+}\right)$ on plant metabolic processes and reactions, including chlorophyll formation, photo-assimilate distribution, phloem-loading, photosynthetic carbon fixation, and partitioning [171]. Deficiency in magnesium increases the concentrations of sugars in leaves and reduces sucrose export to the root $[172,173]$. This reduced sucrose transport could either be due to impaired phloemloading caused by reduced Mg-ATP availability [174] or by reduced metabolic activities of sink organs [175]. Hence, a high shoot-to-root biomass ratio is plausible. Although the allocation of carbon to the youngest leaves appears to be more dominant than to the root $[176,177]$ yet, higher root-over-shoot growth is observed in certain species subjected to low $\mathrm{Mg}$ condition [177]. As such, $\mathrm{Mg}$ starvation reduces the growth of younger leaves compared with that of the roots. The early accumulation of sugars in Mg-deficient leaves results in the downregulation of genes encoding the chlorophyll a/b binding protein, Cab2, which is actively involved in photosynthesis [177]. Another gene encoding companion cell sucrose $/ \mathrm{H}^{+}$symporter, BvSUT1, expressed at the topmost part of the $\mathrm{Mg}$-deficient beet leaves, had no effect on phloem-loading [177]. N- and P-starved plants have exhibited increased carbohydrate transport, but $\mathrm{K}$ and $\mathrm{Mg}$ deficiency is still exempted [163]. More studies should be conducted on the underlying mechanisms involved, as this is poorly understood. These findings depict the influence of mineral nutrient deficiency or supply on the assimilate distribution within the plant organs.

\section{Functional Roles of Sugar Transporters in Mitigating Environmental Stress}

Sugar transport plays a pivotal role in the regulation of plant growth and plant response to environmental stress [64]. Efficient transport of sucrose through the apoplastic pathway in the phloem depends on the involvement of plant sucrose transporters (SUTs) $[74,178]$. As discussed earlier, a considerable number of soluble sugars and sucrosespecific transporters have been identified, including the recently identified family of Sugars Will Eventually be Exported Transporters (SWEETs). SWEETs are integral membrane proteins characterized by seven $\alpha$-helical transmembrane (TM) domains and two MtN3/saliva motifs [179]. The MtN3/Saliva motif is conserved in various organisms, with the proteins harboring this motif functioning as the sugar transporters [74,180].

SWEETs regulate the redistribution of sucrose to the sink under adverse environmental cues, such as drought [181], cold-temperature stress, and elevated $\mathrm{CO}_{2}$ (Figure 4). Arabidopsis thaliana subjected to drought stress exhibited increased sucrose transport to the root when sucrose transporter genes, including AtSWEET11, AtSWEET12, and AtSUC2, are upregulated (Figure 4) $[136,181]$ to rescue the sucrose lost to the apoplast. Similar findings revealed that the sucrose transporter gene OsSUT2 was upregulated in the leaves of rice subjected to drought treatments [182], as enhancing sucrose transport from source leaves to the sink cells necessitates the cellular energy demands of the plant. More recently, the sucrose transporter genes GmSUC2, GmSWEET6, and GmSWEET15 were upregulated in the leaves and roots of soybean seedlings subjected to drought stress, albeit all these upregulations plummeted under prolonged drought. This is an indication of increased capacity of sucrose unloading into seeds and activation of sucrose metabolism during the early seed developmental stage under a drought-stress condition [138]. However, during late seed-filling stages, basipetal sucrose flow from source leaves to seed decreased, leading to an impaired supply of seed (sink) metabolic need, and thus reduced seed weight or yield [142]. Since these transporters trigger sucrose export from source leaves to the root (sink), especially during the early plant-developmental stage, enhancing sucrose transport to the root is promising to optimize root development under drought stress [138]. Rooting depth is an essential trait for determining drought resistance in plants $[183,184]$. To this end, identifying sugar-transporter genes that enhance root-tip elongation can also play an important role in crop-yield improvement. Voothuluru et al. [185] conducted a proteomic analysis on maize root tips subjected to water deficit. The crew [185] indicated a 
strong interaction between ZmSUT2 (localized in the tonoplast) and root elongation, albeit the functional role of this ZmSUT2 transporter in mitigating drought is still unknown. Understanding its functional role will provide an insight into its contribution toward vacuolar-reserve remobilization, since the storage of sugars in the vacuole is imperative for osmotic adjustment under stressed conditions [186,187].

\section{Non-transgenic plant}

\section{Transgenic plant \\ (over-expressing sucrose transporter)}

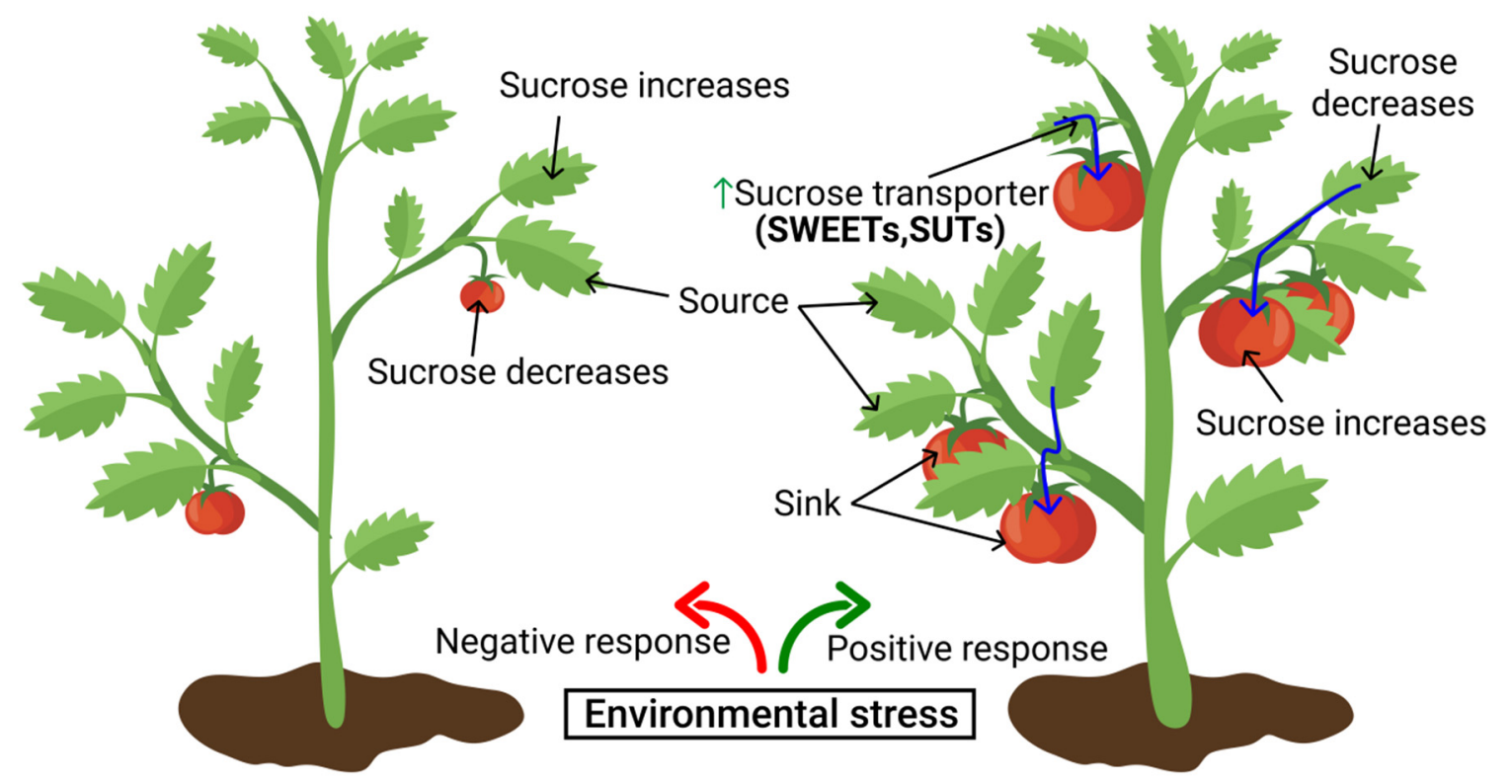

Figure 4. Sugar transporters are involved in environmental stress mitigation. Under stressed conditions, overexpression of sugar transporters (SWEETs, SUTs/SUCs) in plants (right) enhances the transport of soluble sugars, such as sucrose from source leaves to the sink organs for fruit development. Meanwhile, under the same conditions, increased sucrose accumulation in the leaves of nontransgenic plants (left) inhibits sucrose export from the source leaves, limiting sink (fruit) growth and development.

SWEETs also enhance cold tolerance in the tea plant. Wang et al. [188] demonstrated that the increased tolerance of the tea plant (Camellia sinensis) to cold in CSSWEET16overexpressing $(\mathrm{OE})$ lines were due to the combination of different levels of modified sugars. They affirmed that overexpressing CSSWEET16 in atsweet16-1 rescued the high fructose content in the mutant. Similar findings obtained from AtSWEET16 explained the function of CSSWEET16 in altering plant fructose content with an extended effect on glucose and other soluble sugar contents to improve plant tolerance to cold [189]. Under extremes of low temperature (cold), CSSWEET16 OE lines exhibit reduced fructose accumulation in tea leaves, an indication that CSSWEET16 participates in fructose export out of the vacuole. The reduced fructose content under such conditions could have been due to feedback regulation of sugar metabolism, which might affect glucose and other carbohydrates associated with cold tolerance. This finding suggests the contribution of CSSWEET16 to sugar compartmentation across the vacuole and its function in inducing cold tolerance in tea plants [188]. Thus, manipulating these sugar-transporter genes could regulate sugar levels and ultimately stimulate stress tolerance in transgenic plants.

The potential roles of sucrose-transporter genes OsSUT1 and OsSUT2 in photosynthesis and crop-yield improvement was investigated in rice cultivar subjected to elevated $\mathrm{CO}_{2}$ concentration [190]. Rice cultivars that respond poorly to high $\mathrm{CO}_{2}$ exhibits reduced photosynthetic capacity under elevated $\mathrm{CO}_{2}$. The decline in photosynthetic capacity could be strongly associated with the accumulation of soluble sugars. For these cultivars (with 
poor response to additional $\mathrm{CO}_{2}$ ), increased sink relative to the source strength did not affect photosynthesis. No observed change was detected even with the expression of OsSUT1 or OsSUT2. Contrary to this (poor response cultivars), no such increase in soluble sugars or decline in photosynthesis was observed with "strong" cultivars; instead, elevated $\mathrm{CO}_{2}$ increased the expression of the sucrose transporters (OsSUT1 and OsSUT2). It can be inferred from the study that OSSUT1 and OsSUT2 expression may be strongly associated with the improvement of photosynthetic capacity in leaf during the grain-filling stage and ultimately increase the yield of rice subjected to high atmospheric $\mathrm{CO}_{2}$ [190]. Although researchers have focused more on the influence of environmental cues on the source-sink balance, information on how these stressors affect the activities of sugar transporters and their regulation in mitigating environmental stress is still vague.

\section{Integrated Approaches to Crop-Yield Improvement}

Significant crop-yield-improvement potential has contributed immensely to a rising food demand over the past few decades, consistently keeping pace with rising global demand. The history of crop improvements has been a progressive one, from first- to fourth-generation breeding [191-195]. In the 21st century, the world operates in the fourth generation of breeding. It involves both genome editing and precision breeding, which requires a genetic-engineering technique or gene function to determine crop yields. However, a deep understanding of how this generation of breeding is integrated into the source-sink balance within the plant is yet to be clarified.

Photosynthesis has been relied upon for yield improvement in recent years. Linking specific photosynthetic steps to crop yields seems quite tricky at the source level $[192,196]$. As such, Wu et al. [197] launched a cross-scale modeling capacity that linked leaf photosynthesis to crop yield in a manner that addresses the conflicting factor in wheat and sorghum raised in water-limiting and water-sufficient conditions. The model was validated using canopy responses and data on crop biomass and yield for wheat and sorghum from various experimental fields. The three major targets included in the model projected for improving crop yields in C3 (wheat), and C4 (sorghum) photosynthesis include: (i) mesophyll conductance for $\mathrm{CO}_{2}$, (ii) electron-transport capacity, and (iii) the maximum carboxylation rate of $\mathrm{RuBisCO}$. This model revealed that a boost in each of these components by approximately $20 \%$ would individually result in little to no improvement in crop yields. However, a synergetic increase in all three components together boosts the yield of sorghum and wheat to $9.2 \%$ and $12.2 \%$ under a water-sufficient condition, and with more modest improvement when water is deficient. In recent studies, overexpressing RuBisCO in maize increases the rate of maximal $\mathrm{CO}_{2}$ assimilation by $15 \%$, increasing fresh weight. The authors indicated that while no growth disruption was observed under optimal conditions, the overexpressing RuBisCO transgenes could adversely affect yield due to the increased metabolic load [198]. Regulation of stomatal function at the source level has also pointed out some exciting potentials for crop-yield improvement, particularly as stomata offer a promising improvement through water-use efficiency, which is critical to crop-yield improvement. Several other factors improve photosynthetic carbon acquisition and yield at the source level $[199,200]$. However, whether carbon utilization or limitation in source and sink organs are responsible for crop yields has been a confounding issue over several decades.

Studies have been conducted on the activity of sucrose transport in regulating the source-sink relationship, yet trivial progress has been made in relating this to crop-yield improvements [201]. One of the holistic approaches to improve the yield of crops that use apoplastic phloem-loading would be to uncouple phloem-loading from the sucrosesensing system, thereby regulating the partitioning of assimilates. There are two rationales behind this approach. The first is the maintenance of constant rates of sucrose removal from the mesophyll by the expression of the sucrose symporter when there is a decline in phloem-loading, and sink demand becomes low. However, the photosynthetic rate still remains high, even on sucrose removal from the mesophyll cells. Secondly, sugar accumulation can trigger leaf senescence [202]. If sugar accumulation induces senescence, 
the activity of constitutive phloem-loading would reduce the sugar level and subsequently delay senescence. When a reduction in sink demand suppresses photosynthetic rates, and the delay in leaf senescence contributes to a net increase in carboxylation, then maintaining leaf photosynthetic activity depends on the constitutive expression of the symporter. Hence, a net yield increase is realized when this is adopted over a growing season.

Another good approach to yield improvement is overexpressing sucrose transporters in sink cells, which increases the photosynthetic rate and enhances assimilate transport and sink demand. Potato sucrose symporter StSUT1, over-expressed in the storage parenchyma cells of developing pea seeds under the control of a vicilin promoter, resulted in enhanced sucrose influx into cotyledons, as well as increased growth rates of the cotyledon [203]. This result demonstrates that engineering a specific promoter for enhanced sucrose transport is quite feasible and can influence the cotyledon growth rate. A related experiment was conducted by Weichert et al. [204], using a Horedin endosperm-specific promoter to overexpress a barley symporter (Hordeum vulgare) in grain. Increased grain-protein content and decreased overall yield were observed, although not to a statistically significant level, probably because the experiment was not conducted under a controlled condition. It is worth noting that these authors reported notable changes in gene-expression patterns related to carbon metabolism and amino acid biosynthesis, indicating the abundance of carbon and nitrogen depletion. To this end, it can be inferred that the influence of transgenic manipulation of sucrose transport on multiple metabolic pathways could be a significant means of improving yield.

Further studies have described three major $\mathrm{C}$ and $\mathrm{N}$ metabolic enzymes, which include aspartate aminotransferase (GmAspAT), phosphoenolpyruvate carboxylase (ZmPepcase), and glutamine synthetase (NtGS), as the best-practice route that alters source-sink interactions [205] when heterologously coexpressed. These aforementioned practice routes improve $\mathrm{C}$ and $\mathrm{N}$ metabolism, shoot biomass, and seed yield. Even so, the best yield-improvement strategies reported so far have not met the projected need to feed our ever-growing populace by 2050. A significant yield-improvement strategy would be through a series of changes rendered through multigene transformation [206]. An example is a transgenic approach used in alleviating vitamin deficiency affecting up to half of the population in developing countries [206]. Several ongoing projects are currently running this multigene stacking system (employing the Golden Gate toolbox) [18,206].

Two recently developed approaches seem promising regarding our current understanding about the relationship between photosynthesis, plant development, $\mathrm{C}$ and $\mathrm{N}$ transport, and metabolism. The first is the characterization of transcriptional and metabolic changes to enhance our understanding of the mechanism underlying disrupted source-sink relationships in mutants. This would be a prerequisite to allowing rational engineering of crop yields. The second approach is the modeling strategies and their potential impact on the whole-plant scale, which represents an important testing ground for combined metabolic interventions [8]. In the future, the widespread use of this model seems pragmatic because an overview of the whole-plant physiology will be provided. Other approaches are the adoption of new tools based on hybrid diploid breeding [207,208], speed-breeding techniques [209], and the promising potentials offered by CRISPR [210].

\section{Conclusions}

Plant growth and development are greatly enhanced when the sucrose in the source organ balances with the metabolic needs of the heterotrophic sink. Thus, the strategies involved in improving photosynthetic carbon assimilation for sucrose synthesis and sucrose transport to and its utilization at the sink level become imperative. However, even when these processes involved in sucrose utilization for improved seed (sink) yield are in place, disruptions resulting from environmental cues might emerge. Several questions have arisen as to how photosynthetic activity in both C3 and C4 crops could be further improved or maximized. Such rising issues include: (i) whether evolution has taken over the photosynthetic role in every ecological niche, (ii) whether plants can maximize these 
ever-increasing $\mathrm{CO}_{2}$ concentrations, and (iii) whether breeding programs have influenced the variation between crops for agro-ecosystems and their wild progenitors. All of these questions regarding the potential to fully optimize photosynthesis most likely are still unanswered. In a world of increasing atmospheric carbon-dioxide that is accompanied by environmental deterioration, enhancing sucrose distribution and utilization at the sink is a crucial step in optimizing photosynthesis and maximizing crop yields.

Dynamic regulatory processes mediate the complex interaction of source and sink activity between different organs in the vascular system of the plant. Phloem transport of sugar is closely regulated and highly sensitive to fluctuations in plant environmental cues, resulting in appreciable alterations in the quota of carbon allocated to the sinks. However, there is sparse information on the impact of environmental stress on the phloem transport of photo-assimilates from source to sink organs. Despite the significant roles of sugar transporter in the translocation of sugar within the plants, little is known about how sugar transporter operates under stressed conditions at the molecular level. This is mainly because most studies are mostly tailored toward the physiological responses, rather than the molecular responses, of sugar transporters to these stress factors. Thus, the mechanisms and signals involved in the regulation of source-to-sink activity and their response to the environment should be explored. Knowledge of these will better facilitate further research on the improvement of crop yields, with special focus on sucrose synthesis, transport, and utilization at the sink and underlying environmental cues affecting these processes.

Author Contributions: Conceptualization, O.O.A., Q.W. and H.L.; writing-original draft preparation, O.O.A.; writing-review and editing, O.O.A.; investigation, O.O.A.; visualization, O.O.A. and C.L.; validation, O.O.A., Q.W. and C.L.; supervision, Q.W. and H.L.; funding acquisition, Q.W. and H.L. All authors have read and agreed to the published version of the manuscript.

Funding: This work was supported by the China Scholarships Council, International Foundation of Tobacco Research Institute of Chinese Academy of Agricultural Sciences (IFT202102); the Agricultural Science and Technology Innovation Program (ASTIP-TRIC02, ASTIP-TRIC03); and the Fundamental Research Funds for China Agricultural Academy of Sciences (1610232021002).

Data Availability Statement: Not applicable.

Acknowledgments: We appreciate S. Hauser (International Institute of Tropical Agriculture) for proofreading the manuscript. We also thank Osanyintuyi A., Mao J., Aluko J.F., Anthony V., Omotoso O., Ajireloja T., Obianwuna U., and Aluko O. for their insightful suggestions.

Conflicts of Interest: The authors declare no conflict of interest.

\section{References}

1. Taiz, L.; Zeiger, E.; Moller, I.M.; Murphy, A. Plant Physiology and Development, 6th ed.; Oxford University Press: New York, NY, USA, 2018; p. 31.

2. Osorio, S.; Ruan, Y.L.; Fernie, A.R. An update on source-to-sink carbon partitioning in tomato. Front. Plant Sci. 2014,5 , 516. [CrossRef]

3. Lemoine, R. Sucrose transporters in plants: Update on function and structure. Biochim. Biophys. Acta (BBA) Biomembr. 2000, 1465, 246-262. [CrossRef]

4. Kircher, S.; Schopfer, P. Photosynthetic sucrose acts as cotyledon-derived long-distance signal to control root growth during early seedling development in Arabidopsis. Proc. Natl. Acad. Sci. USA 2012, 109, 11217-11221. [CrossRef]

5. Mason, M.G.; Ross, J.J.; Babst, B.A.; Wienclaw, B.N.; Beveridge, C.A. Sugar demand, not auxin, is the initial regulator of apical dominance. Proc. Natl. Acad. Sci. USA 2014, 111, 6092-6097. [CrossRef]

6. Ribeiro, T.H.C.; Fernandes-Brum, C.N.; de Souza, C.R.; Dias, F.A.N.; de Almeida-Junior, O.; de Albuquerque Regina, M.; de Oliveira, K.K.P.; dos Reis, G.L.; Oliveira, L.M.; de Paula Fernandes, F. Transcriptome analyses suggest that changes in fungal endophyte lifestyle could be involved in grapevine bud necrosis. Sci. Rep. 2020, 10, 1-13. [CrossRef] [PubMed]

7. Mason, T.; Maskell, E. Studies on the transport of carbohydrates in the cotton plant: II. The factors determining the rate and the direction of movement of sugars. Ann. Bot. 1928, 42, 571-636. [CrossRef]

8. Sonnewald, U.; Fernie, A.R. Next-generation strategies for understanding and influencing source-sink relations in crop plants. Curr. Opin. Plant Biol. 2018, 43, 63-70. [CrossRef] [PubMed]

9. Chang, T.G.; Zhu, X.G.; Raines, C. Source-sink interaction: A century old concept under the light of modern molecular systems biology. J. Exp. Bot. 2017, 68, 4417-4431. [CrossRef] 
10. Ainsworth, E.A.; Long, S.P. What have we learned from 15 years of free-air $\mathrm{CO}_{2}$ enrichment (FACE)? A meta-analytic review of the responses of photosynthesis, canopy properties and plant production to rising $\mathrm{CO}_{2}$. New Phytol. 2005, 165, 351-372. [CrossRef]

11. Wilson, R.H.; Martin-Avila, E.; Conlan, C.; Whitney, S.M. An improved Escherichia coli screen for Rubisco identifies a proteinprotein interface that can enhance $\mathrm{CO}_{2}$-fixation kinetics. J. Biol. Chem. 2018, 293, 18-27. [CrossRef] [PubMed]

12. Morgun, V.; Priadkina, G.; Zborovska, O. Dependence of main shoot ear grain yield from stem deposited ability of winter wheat varieties. Ukr. J. Ecol. 2018, 8, 113-118.

13. Flexas, J. Genetic improvement of leaf photosynthesis and intrinsic water use efficiency in C3 plants: Why so much little success? Plant Sci. 2016, 251, 155-161. [CrossRef]

14. Andralojc, P.J.; Carmo-Silva, E.; Degen, G.E.; Parry, M.A. Increasing metabolic potential: C-fixation. Essays Biochem. 2018, 62, 109-118.

15. Sage, R.F. A portrait of the C4 photosynthetic family on the 50th anniversary of its discovery: Species number, evolutionary lineages, and Hall of Fame. J. Exp. Bot. 2017, 68, e11-e28. [CrossRef]

16. Chowrasia, S.; Mondal, T.K. C4 photosynthesis with Kranz anatomy evolved in the Oryza coarctata Roxb. bioRxiv 2020. [CrossRef]

17. Ingle, A.P.; Philippini, R.R.; Martiniano, S.; Marcelino, P.R.F.; Gupta, I.; Prasad, S.; da Silva, S.S. Bioresources and their significance: Prospects and obstacles. In Current Developments in Biotechnology and Bioengineering; Elsevier: Amsterdam, The Netherlands, 2020; pp. 3-40.

18. Fernie, A.R.; Bachem, C.W.; Helariutta, Y.; Neuhaus, H.E.; Prat, S.; Ruan, Y.-L.; Stitt, M.; Sweetlove, L.J.; Tegeder, M.; Wahl, V. Synchronization of developmental, molecular and metabolic aspects of source-sink interactions. Nat. Plants 2020, 6, 55-66. [CrossRef] [PubMed]

19. Sharwood, R.E.; Sonawane, B.V.; Ghannoum, O.; Whitney, S.M. Improved analysis of C4 and C3 photosynthesis via refined in vitro assays of their carbon fixation biochemistry. J. Exp. Bot. 2016, 67, 3137-3148. [CrossRef]

20. Weber, A.P.; Bar-Even, A. Update: Improving the efficiency of photosynthetic carbon reactions. Plant Physiol. 2019, 179, 803-812. [CrossRef] [PubMed]

21. Long, S.P.; Marshall-Colon, A.; Zhu, X.-G. Meeting the global food demand of the future by engineering crop photosynthesis and yield potential. Cell 2015, 161, 56-66. [CrossRef] [PubMed]

22. Rae, B.D.; Long, B.M.; Förster, B.; Nguyen, N.D.; Velanis, C.N.; Atkinson, N.; Hee, W.Y.; Mukherjee, B.; Price, G.D.; McCormick, A.J. Progress and challenges of engineering a biophysical $\mathrm{CO}_{2}$-concentrating mechanism into higher plants. J. Exp. Bot. 2017, 68, 3717-3737. [CrossRef] [PubMed]

23. Orr, D.J.; Pereira, A.M.; da Fonseca Pereira, P.; Pereira-Lima, Í.A.; Zsögön, A.; Araújo, W.L. Engineering photosynthesis: Progress and perspectives. F1000Research 2017, 6. [CrossRef] [PubMed]

24. Kromdijk, J.; Głowacka, K.; Leonelli, L.; Gabilly, S.T.; Iwai, M.; Niyogi, K.K.; Long, S.P. Improving photosynthesis and crop productivity by accelerating recovery from photoprotection. Science 2016, 354, 857-861. [CrossRef] [PubMed]

25. Betti, M.; Bauwe, H.; Busch, F.A.; Fernie, A.R.; Keech, O.; Levey, M.; Ort, D.R.; Parry, M.A.; Sage, R.; Timm, S. Manipulating photorespiration to increase plant productivity: Recent advances and perspectives for crop improvement. J. Exp. Bot. 2016, 67, 2977-2988. [CrossRef] [PubMed]

26. Głowacka, K.; Kromdijk, J.; Kucera, K.; Xie, J.; Cavanagh, A.P.; Leonelli, L.; Leakey, A.D.; Ort, D.R.; Niyogi, K.K.; Long, S.P. Photosystem II Subunit S overexpression increases the efficiency of water use in a field-grown crop. Nat. Commun. 2018, 9, 1-9. [CrossRef] [PubMed]

27. Papanatsiou, M.; Petersen, J.; Henderson, L.; Wang, Y.; Christie, J.; Blatt, M. Optogenetic manipulation of stomatal kinetics improves carbon assimilation, water use, and growth. Science 2019, 363, 1456-1459. [CrossRef]

28. Baslam, M.; Mitsui, T.; Hodges, M.; Priesack, E.; Herritt, M.T.; Aranjuelo, I.; Sanz-Saez, A. Photosynthesis in a Changing Global Climate: Scaling Up and Scaling Down in Crops. Front. Plant Sci. 2020, 11, 882. [CrossRef]

29. Prather, M.; Flato, G.; Friedlingstein, P.; Jones, C.; Lamarque, J.; Liao, H.; Rasch, P. Annex II: Climate system scenario tables. Clim. Chang. 2013, 2013, 1395-1445.

30. Rowlands, D.J.; Frame, D.J.; Ackerley, D.; Aina, T.; Booth, B.B.; Christensen, C.; Collins, M.; Faull, N.; Forest, C.E.; Grandey, B.S. Broad range of 2050 warming from an observationally constrained large climate model ensemble. Nat. Geosci. 2012, 5, 256-260. [CrossRef]

31. Ort, D.R.; Merchant, S.S.; Alric, J.; Barkan, A.; Blankenship, R.E.; Bock, R.; Croce, R.; Hanson, M.R.; Hibberd, J.M.; Long, S.P. Redesigning photosynthesis to sustainably meet global food and bioenergy demand. Proc. Natl. Acad. Sci. USA 2015, 112, 8529-8536. [CrossRef]

32. Raines, C.A. Transgenic approaches to manipulate the environmental responses of the C3 carbon fixation cycle. Plant Cell Environ. 2006, 29, 331-339. [CrossRef]

33. Raines, C.A. Increasing photosynthetic carbon assimilation in C3 plants to improve crop yield: Current and future strategies. Plant Physiol. 2011, 155, 36-42. [CrossRef]

34. Von Caemmerer, S. Biochemical Models of Leaf Photosynthesis; Csiro Publishing: Collingwood, VIC, Australia, 2000.

35. Long, S.P.; Ainsworth, E.A.; Rogers, A.; Ort, D.R. Rising atmospheric carbon dioxide: Plants FACE the future. Annu. Rev. Plant Biol. 2004, 55, 591-628. [CrossRef] [PubMed] 
36. Simkin, A.J.; Lopez-Calcagno, P.E.; Davey, P.A.; Headland, L.R.; Lawson, T.; Timm, S.; Bauwe, H.; Raines, C.A. Simultaneous stimulation of sedoheptulose 1, 7-bisphosphatase, fructose 1, 6-bisphophate aldolase and the photorespiratory glycine decarboxylase-H protein increases $\mathrm{CO}_{2}$ assimilation, vegetative biomass and seed yield in Arabidopsis. Plant Biotechnol. J. 2017, 15, 805-816. [CrossRef] [PubMed]

37. Simkin, A.J.; McAusland, L.; Headland, L.R.; Lawson, T.; Raines, C.A. Multigene manipulation of photosynthetic carbon assimilation increases $\mathrm{CO}_{2}$ fixation and biomass yield in tobacco. J. Exp. Bot. 2015, 66, 4075-4090. [CrossRef] [PubMed]

38. Lefebvre, S.; Lawson, T.; Fryer, M.; Zakhleniuk, O.V.; Lloyd, J.C.; Raines, C.A. Increased sedoheptulose-1, 7-bisphosphatase activity in transgenic tobacco plants stimulates photosynthesis and growth from an early stage in development. Plant Physiol. 2005, 138, 451-460. [CrossRef] [PubMed]

39. Ding, F.; Wang, M.; Zhang, S.; Ai, X. Changes in SBPase activity influence photosynthetic capacity, growth, and tolerance to chilling stress in transgenic tomato plants. Sci. Rep. 2016, 6, 1-14. [CrossRef]

40. Driever, S.M.; Simkin, A.J.; Alotaibi, S.; Fisk, S.J.; Madgwick, P.J.; Sparks, C.A.; Jones, H.D.; Lawson, T.; Parry, M.A.; Raines, C.A. Increased SBPase activity improves photosynthesis and grain yield in wheat grown in greenhouse conditions. Philos. Trans. $R$. Soc. B Biol. Sci. 2017, 372, 20160384. [CrossRef] [PubMed]

41. Köhler, I.H.; Ruiz-Vera, U.M.; VanLoocke, A.; Thomey, M.L.; Clemente, T.; Long, S.P.; Ort, D.R.; Bernacchi, C.J. Expression of cyanobacterial FBP/SBPase in soybean prevents yield depression under future climate conditions. J. Exp. Bot. 2017, 68, 715-726. [CrossRef]

42. Fuso Nerini, F.; Sovacool, B.; Hughes, N.; Cozzi, L.; Cosgrave, E.; Howells, M.; Tavoni, M.; Tomei, J.; Zerriffi, H.; Milligan, B. Connecting climate action with other Sustainable Development Goals. Nat. Sustain. 2019, 2, 674-680. [CrossRef]

43. Simkin, A.J.; López-Calcagno, P.E.; Raines, C.A. Feeding the world: Improving photosynthetic efficiency for sustainable crop production. J. Exp. Bot. 2019, 70, 1119-1140. [CrossRef]

44. The Lancet HIV. The syndemic threat of food insecurity and HIV. Lancet HIV 2020, 7. [CrossRef]

45. Taylor, S.F.; Roberts, M.J.; Milligan, B.; Ncwadi, R. Measurement and implications of marine food security in the Western Indian Ocean: An impending crisis? Food Secur. 2019, 11, 1395-1415. [CrossRef]

46. Gu, J.; Zhou, Z.; Li, Z.; Chen, Y.; Wang, Z.; Zhang, H. Rice (Oryza sativa L.) with reduced chlorophyll content exhibit higher photosynthetic rate and efficiency, improved canopy light distribution, and greater yields than normally pigmented plants. Field Crop. Res. 2017, 200, 58-70. [CrossRef]

47. Jonik, C.; Sonnewald, U.; Hajirezaei, M.R.; Flügge, U.I.; Ludewig, F. Simultaneous boosting of source and sink capacities doubles tuber starch yield of potato plants. Plant Biotechnol. J. 2012, 10, 1088-1098. [CrossRef]

48. Nölke, G.; Houdelet, M.; Kreuzaler, F.; Peterhänsel, C.; Schillberg, S. The expression of a recombinant glycolate dehydrogenase polyprotein in potato (Solanum tuberosum) plastids strongly enhances photosynthesis and tuber yield. Plant Biotechnol. J. 2014, 12, 734-742. [CrossRef] [PubMed]

49. Ainsworth, E.A.; Bush, D.R. Carbohydrate export from the leaf: A highly regulated process and target to enhance photosynthesis and productivity. Plant Physiol. 2011, 155, 64-69. [CrossRef]

50. Oszvald, M.; Primavesi, L.F.; Griffiths, C.A.; Cohn, J.; Basu, S.S.; Nuccio, M.L.; Paul, M.J. Trehalose 6-phosphate regulates photosynthesis and assimilate partitioning in reproductive tissue. Plant Physiol. 2018, 176, 2623-2638. [CrossRef] [PubMed]

51. Zhang, C.; Turgeon, R. Downregulating the sucrose transporter VpSUT1 in Verbascum phoeniceum does not inhibit phloem loading. Proc. Natl. Acad. Sci. USA 2009, 106, 18849-18854. [CrossRef]

52. Stitt, M.; Lunn, J.; Usadel, B. Arabidopsis and primary photosynthetic metabolism-more than the icing on the cake. Plant J. 2010, 61, 1067-1091. [CrossRef] [PubMed]

53. Kaschuk, G.; Hungria, M.; Leffelaar, P.; Giller, K.; Kuyper, T. Differences in photosynthetic behaviour and leaf senescence of soybean (Glycine max [L.] Merrill) dependent on N2 fixation or nitrate supply. Plant Biol. 2010, 12, 60-69. [CrossRef]

54. Petridis, A.; van der Kaay, J.; Sungurtas, J.; Verrall, S.R.; McCallum, S.; Graham, J.; Hancock, R.D. Photosynthetic plasticity allows blueberry (Vaccinium corymbosum L.) plants to compensate for yield loss under conditions of high sink demand. Environ. Exp. Bot. 2020, 174. [CrossRef]

55. Ainsworth, E.A.; Long, S.P. 30 years of free-air carbon dioxide enrichment (FACE): What have we learned about future crop productivity and its potential for adaptation? Glob. Chang. Biol. 2021, 27, 27-49. [CrossRef]

56. Arp, W. Effects of source-sink relations on photosynthetic acclimation to elevated $\mathrm{CO}_{2}$. Plant Cell Environ. 1991, 14, 869-875. [CrossRef]

57. Leakey, A.D.; Ainsworth, E.A.; Bernacchi, C.J.; Rogers, A.; Long, S.P.; Ort, D.R. Elevated $\mathrm{CO}_{2}$ effects on plant carbon, nitrogen, and water relations: Six important lessons from FACE. J. Exp. Bot. 2009, 60, 2859-2876. [CrossRef]

58. Parvin, S.; Uddin, S.; Tausz-Posch, S.; Armstrong, R.; Tausz, M. Carbon sink strength of nodules but not other organs modulates photosynthesis of faba bean (Vicia faba) grown under elevated $\left[\mathrm{CO}_{2}\right]$ and different water supply. New Phytol. 2020, 227, 132-145. [CrossRef] [PubMed]

59. Davey, P.; Olcer, H.; Zakhleniuk, O.; Bernacchi, C.; Calfapietra, C.; Long, S.; Raines, C. Can fast-growing plantation trees escape biochemical down-regulation of photosynthesis when grown throughout their complete production cycle in the open air under elevated carbon dioxide? Plant Cell Environ. 2006, 29, 1235-1244. [CrossRef] 
60. Sulpice, R.; Flis, A.; Ivakov, A.A.; Apelt, F.; Krohn, N.; Encke, B.; Abel, C.; Feil, R.; Lunn, J.E.; Stitt, M. Arabidopsis coordinates the diurnal regulation of carbon allocation and growth across a wide range of photoperiods. Mol. Plant 2014, 7, 137-155. [CrossRef] [PubMed]

61. Kolling, K.; Thalmann, M.; Muller, A.; Jenny, C.; Zeeman, S.C. Carbon partitioning in Arabidopsis thaliana is a dynamic process controlled by the plants metabolic status and its circadian clock. Plant Cell Environ. 2015, 38, 1965-1979. [CrossRef]

62. Weraduwage, S.M.; Chen, J.; Anozie, F.C.; Morales, A.; Weise, S.E.; Sharkey, T.D. The relationship between leaf area growth and biomass accumulation in Arabidopsis thaliana. Front. Plant Sci. 2015, 6, 167. [CrossRef] [PubMed]

63. Sulpice, R.; Pyl, E.-T.; Ishihara, H.; Trenkamp, S.; Steinfath, M.; Witucka-Wall, H.; Gibon, Y.; Usadel, B.; Poree, F.; Piques, M.C. Starch as a major integrator in the regulation of plant growth. Proc. Natl. Acad. Sci. USA 2009, 106, 10348-10353. [CrossRef]

64. Lemoine, R.; La Camera, S.; Atanassova, R.; Dédaldéchamp, F.; Allario, T.; Pourtau, N.; Bonnemain, J.-L.; Laloi, M.; CoutosThévenot, P.; Maurousset, L. Source-to-sink transport of sugar and regulation by environmental factors. Front. Plant Sci. 2013, 4, 272. [CrossRef]

65. Minchin, P.; Lacointe, A. New understanding on phloem physiology and possible consequences for modelling long-distance carbon transport. New Phytol. 2005, 166, 771-779. [CrossRef]

66. Rennie, E.A.; Turgeon, R. A comprehensive picture of phloem loading strategies. Proc. Natl. Acad. Sci. USA 2009, 106, 14162-14167. [CrossRef] [PubMed]

67. van Bel, A.J. The phloem, a miracle of ingenuity. Plant Cell Environ. 2003, 26, 125-149. [CrossRef]

68. Braun, D.M.; Wang, L.; Ruan, Y.-L. Understanding and manipulating sucrose phloem loading, unloading, metabolism, and signalling to enhance crop yield and food security. J. Exp. Bot. 2014, 65, 1713-1735. [CrossRef]

69. Milne, R.J.; Perroux, J.M.; Rae, A.L.; Reinders, A.; Ward, J.M.; Offler, C.E.; Patrick, J.W.; Grof, C.P. Sucrose transporter localization and function in phloem unloading in developing stems. Plant Physiol. 2017, 173, 1330-1341. [CrossRef] [PubMed]

70. Turgeon, R. The role of phloem loading reconsidered. Plant Physiol. 2010, 152, 1817-1823. [CrossRef] [PubMed]

71. Ayre, B.G.; Turgeon, R. Export of Photosynthates from the Leaf. In The Leaf: A Platform for Performing Photosynthesis; Springer: Berlin/Heidelberg, Germany, 2018; pp. 55-79.

72. Milne, R.J.; Grof, C.P.; Patrick, J.W. Mechanisms of phloem unloading: Shaped by cellular pathways, their conductances and sink function. Curr. Opin. Plant Biol. 2018, 43, 8-15. [CrossRef]

73. Eom, J.-S.; Cho, J.-I.; Reinders, A.; Lee, S.-W.; Yoo, Y.; Tuan, P.Q.; Choi, S.-B.; Bang, G.; Park, Y.-I.; Cho, M.-H. Impaired function of the tonoplast-localized sucrose transporter in rice, OsSUT2, limits the transport of vacuolar reserve sucrose and affects plant growth. Plant Physiol. 2011, 157, 109-119. [CrossRef]

74. Chen, L.-Q.; Qu, X.-Q.; Hou, B.-H.; Sosso, D.; Osorio, S.; Fernie, A.R.; Frommer, W.B. Sucrose efflux mediated by SWEET proteins as a key step for phloem transport. Science 2012, 335, 207-211. [CrossRef]

75. Ma, L.; Zhang, D.; Miao, Q.; Yang, J.; Xuan, Y.; Hu, Y. Essential role of sugar transporter OsSWEET11 during the early stage of rice grain filling. Plant Cell Physiol. 2017, 58, 863-873. [CrossRef]

76. Rodrigues, C.M.; Müdsam, C.; Keller, I.; Zierer, W.; Czarnecki, O.; Corral, J.M.; Reinhardt, F.; Nieberl, P.; Fiedler-Wiechers, K.; Sommer, F. Vernalization alters sink and source identities and reverses phloem translocation from taproots to shoots in sugar beet. Plant Cell 2020, 32, 3206-3223. [CrossRef] [PubMed]

77. Zhang, C.; Bian, Y.; Hou, S.; Li, X. Sugar transport played a more important role than sugar biosynthesis in fruit sugar accumulation during Chinese jujube domestication. Planta 2018, 248, 1187-1199. [CrossRef] [PubMed]

78. Godt, D.; Roitsch, T. The developmental and organ specific expression of sucrose cleaving enzymes in sugar beet suggests a transition between apoplasmic and symplasmic phloem unloading in the tap roots. Plant Physiol. Biochem. 2006, 44, 656-665. [CrossRef] [PubMed]

79. Zhang, L.-Y.; Peng, Y.-B.; Pelleschi-Travier, S.; Fan, Y.; Lu, Y.-F.; Lu, Y.-M.; Gao, X.-P.; Shen, Y.-Y.; Delrot, S.; Zhang, D.-P. Evidence for apoplasmic phloem unloading in developing apple fruit. Plant Physiol. 2004, 135, 574-586. [CrossRef]

80. Abelenda, J.A.; Bergonzi, S.; Oortwijn, M.; Sonnewald, S.; Du, M.; Visser, R.G.; Sonnewald, U.; Bachem, C.W. Source-sink regulation is mediated by interaction of an FT Homolog with a SWEET protein in potato. Curr. Biol. 2019, 29, 1178-1186.e6. [CrossRef] [PubMed]

81. Ma, S.; Li, Y.; Li, X.; Sui, X.; Zhang, Z. Phloem unloading strategies and mechanisms in crop fruits. J. Plant Growth Regul. 2019, 38, 494-500. [CrossRef]

82. Ru, L.; Osorio, S.; Wang, L.; Fernie, A.R.; Patrick, J.W.; Ruan, Y.-L. Transcriptomic and metabolomics responses to elevated cell wall invertase activity during tomato fruit set. J. Exp. Bot. 2017, 68, 4263-4279. [CrossRef]

83. Tang, F.; Zhu, J.; Wang, T.; Shao, D. Water deficit effects on carbon metabolism in cotton fibers during fiber elongation phase. Acta Physiol. Plant. 2017, 39, 69. [CrossRef]

84. Weber, H.; Buchner, P.; Borisjuk, L.; Wobus, U. Sucrose metabolism during cotyledon development of Vicia faba L. is controlled by the concerted action of both sucrose-phosphate synthase and sucrose synthase: Expression patterns, metabolic regulation and implications for seed development. Plant J. 1996, 9, 841-850. [CrossRef]

85. Makino, A.; Mae, T. Photosynthesis and plant growth at elevated levels of $\mathrm{CO}_{2}$. Plant Cell Physiol. 1999, 40, 999-1006. [CrossRef]

86. Zheng, Y.; Li, F.; Hao, L.; Yu, J.; Guo, L.; Zhou, H.; Ma, C.; Zhang, X.; Xu, M. Elevated $\mathrm{CO}_{2}$ concentration induces photosynthetic down-regulation with changes in leaf structure, non-structural carbohydrates and nitrogen content of soybean. BMC Plant Biol. 2019, 19, 255. [CrossRef] 
87. Kanemoto, K.; Yamashita, Y.; Ozawa, T.; Imanishi, N.; Nguyen, N.T.; Suwa, R.; Mohapatra, P.K.; Kanai, S.; Moghaieb, R.E.; Ito, J. Photosynthetic acclimation to elevated $\mathrm{CO}_{2}$ is dependent on $\mathrm{N}$ partitioning and transpiration in soybean. Plant Sci. 2009, 177, 398-403. [CrossRef]

88. Eichelmann, H.; Talts, E.; Oja, V.; Padu, E.; Laisk, A. Rubisco in planta k cat is regulated in balance with photosynthetic electron transport. J. Exp. Bot. 2009, 60, 4077-4088. [CrossRef] [PubMed]

89. Atkin, O. New Phytologist and the 'fate' of carbon in terrestrial ecosystems. New Phytol. 2015, 205, 1-3. [CrossRef] [PubMed]

90. Stitt, M. Rising $\mathrm{CO}_{2}$ levels and their potential significance for carbon flow in photosynthetic cells. Plant Cell Environ. 1991, 14, 741-762. [CrossRef]

91. Wang, N.; Nobel, P.S. Doubling the $\mathrm{CO}_{2}$ concentration enhanced the activity of carbohydrate-metabolism enzymes, source carbohydrate production, photoassimilate transport, and sink strength for Opuntia ficus-indica. Plant Physiol. 1996, 110, 893-902. [CrossRef]

92. Cock, J.H.; Yoshida, S. Changing sink and source relations in rice (Oryza sativa L.) using carbon dioxide enrichment in the field. Soil Sci. Plant Nutr. 1973, 19, 229-234. [CrossRef]

93. Nakano, H.; Yoshinaga, S.; Takai, T.; Arai-Sanoh, Y.; Kondo, K.; Yamamoto, T.; Sakai, H.; Tokida, T.; Usui, Y.; Nakamura, H. Quantitative trait loci for large sink capacity enhance rice grain yield under free-air $\mathrm{CO}_{2}$ enrichment conditions. Sci. Rep. 2017, 7, 1-10. [CrossRef]

94. Hasegawa, T.; Sakai, H.; Tokida, T.; Nakamura, H.; Zhu, C.; Usui, Y.; Yoshimoto, M.; Fukuoka, M.; Wakatsuki, H.; Katayanagi, N. Rice cultivar responses to elevated $\mathrm{CO}_{2}$ at two free-air $\mathrm{CO}_{2}$ enrichment (FACE) sites in Japan. Funct. Plant Biol. 2013, 40, 148-159. [CrossRef]

95. Hasegawa, T.; Sakai, H.; Tokida, T.; Usui, Y.; Yoshimoto, M.; Fukuoka, M.; Nakamura, H.; Shimono, H.; Okada, M. Rice free-air carbon dioxide enrichment studies to improve assessment of climate change effects on rice agriculture. Improv. Model. Tools Assess Clim. Chang. Eff. Crop Response 2016, 7, 45-68.

96. Nakano, H.; Makino, A.; Mae, T. Effects of panicle removal on the photosynthetic characteristics of the flag leaf of rice plants during the ripening stage. Plant Cell Physiol. 1995, 36, 653-659.

97. Shinano, T.; Osawa, M.; Soejima, H.; Osaki, M. Effect of panicle removal on cytokinin level in the xylem and nitrogen uptake activity of rice. Soil Sci. Plant Nutr. 2006, 52, 331-340. [CrossRef]

98. Shimono, H.; Suzuki, K.; Aoki, K.; Hasegawa, T.; Okada, M. Effect of panicle removal on photosynthetic acclimation under elevated $\mathrm{CO}_{2}$ in rice. Photosynthetica 2010, 48, 530-536. [CrossRef]

99. Jing, L.-Q.; Wu, Y.-Z.; Zhuang, S.-T.; Wang, Y.-X.; Zhu, J.-G.; Wang, Y.-L.; Yang, L.-X. Effects of $\mathrm{CO}_{2}$ enrichment and spikelet removal on rice quality under open-air field conditions. J. Integr. Agric. 2016, 15, 2012-2022. [CrossRef]

100. Fabre, D.; Yin, X.; Dingkuhn, M.; Clement-Vidal, A.; Roques, S.; Rouan, L.; Soutiras, A.; Luquet, D. Is triose phosphate utilization involved in the feedback inhibition of photosynthesis in rice under conditions of sink limitation? J. Exp. Bot. 2019, 70, 5773-5785. [CrossRef] [PubMed]

101. Page, E.R.; Liu, W.; Cerrudo, D.; Lee, E.A.; Swanton, C.J. Shade avoidance influences stress tolerance in maize. Weed Sci. 2011, 59, 326-334. [CrossRef]

102. Chen, X.; Yao, Q.; Gao, X.; Jiang, C.; Harberd, N.P.; Fu, X. Shoot-to-root mobile transcription factor HY5 coordinates plant carbon and nitrogen acquisition. Curr. Biol. 2016, 26, 640-646. [CrossRef] [PubMed]

103. Oliveira, P.M.R.; Rodrigues, M.A.; Goncalves, A.Z.; Kerbauy, G.B. Exposure of Catasetum fimbriatum aerial roots to light coordinates carbon partitioning between source and sink organs in an auxin dependent manner. Plant Physiol. Biochem. 2019, 135, 341-347. [CrossRef]

104. Zeeman, S.C.; Kossmann, J.; Smith, A.M. Starch: Its metabolism, evolution, and biotechnological modification in plants. Annu. Rev. Plant Biol. 2010, 61, 209-234. [CrossRef]

105. Smith, A.M.; Stitt, M. Coordination of carbon supply and plant growth. Plant Cell Environ. 2007, 30, 1126-1149. [CrossRef]

106. Pyl, E.-T.; Piques, M.; Ivakov, A.; Schulze, W.; Ishihara, H.; Stitt, M.; Sulpice, R. Metabolism and growth in Arabidopsis depend on the daytime temperature but are temperature-compensated against cool nights. Plant Cell 2012, 24, 2443-2469. [CrossRef] [PubMed]

107. Poire, R.; Wiese-Klinkenberg, A.; Parent, B.; Mielewczik, M.; Schurr, U.; Tardieu, F.; Walter, A. Diel time-courses of leaf growth in monocot and dicot species: Endogenous rhythms and temperature effects. J. Exp. Bot. 2010, 61, 1751-1759. [CrossRef] [PubMed]

108. Yazdanbakhsh, N.; Sulpice, R.; Graf, A.; Stitt, M.; Fisahn, J. Circadian control of root elongation and C partitioning in Arabidopsis thaliana. Plant Cell Environ. 2011, 34, 877-894. [CrossRef]

109. Pilkington, S.M.; Encke, B.; Krohn, N.; Hoehne, M.; Stitt, M.; Pyl, E.T. Relationship between starch degradation and carbon demand for maintenance and growth in Arabidopsis thaliana in different irradiance and temperature regimes. Plant Cell Environ. 2015, 38, 157-171. [CrossRef] [PubMed]

110. Amiard, V.; Demmig-Adams, B.; Mueh, K.E.; Turgeon, R.; Combs, A.F.; Adams, W.W. Role of light and jasmonic acid signaling in regulating foliar phloem cell wall ingrowth development. New Phytol. 2007, 173, 722-731. [CrossRef]

111. Lambers, H.; Oliveira, R.S. Photosynthesis, Respiration, and Long-Distance Transport: Long Distance Transport of Assimilates. In Plant Physiological Ecology; Springer: Berlin/Heidelberg, Germany, 2019; pp. 173-186. 
112. Amiard, V.; Mueh, K.E.; Demmig-Adams, B.; Ebbert, V.; Turgeon, R.; Adams, W.W. Anatomical and photosynthetic acclimation to the light environment in species with differing mechanisms of phloem loading. Proc. Natl. Acad. Sci. USA 2005, 102, 12968-12973. [CrossRef]

113. Amist, N.; Singh, N. The role of sugars in the regulation of environmental stress. In Plant Life under Changing Environment; Elsevier: Amsterdam, The Netherlands, 2020; pp. 497-512.

114. Yang, L.Y.; Yang, S.L.; Li, J.Y.; Ma, J.H.; Pang, T.; Zou, C.M.; He, B.; Gong, M. Effects of different growth temperatures on growth, development, and plastid pigments metabolism of tobacco (Nicotiana tabacum L.) plants. Bot. Stud. 2018, 59, 5. [CrossRef]

115. Choquette, N.E.; Ainsworth, E.A.; Bezodis, W.; Cavanagh, A.P. Ozone tolerant maize hybrids maintain Rubisco content and activity during long-term exposure in the field. Plant Cell Environ. 2020, 43, 3033-3047. [CrossRef]

116. Hebbar, K.; Apshara, E.; Chandran, K.; Prasad, P.V. Effect of elevated $\mathrm{CO}_{2}$, high temperature, and water deficit on growth, photosynthesis, and whole plant water use efficiency of cocoa (Theobroma cacao L.). Int. J. Biometeorol. 2020, 64, 47-57. [CrossRef] [PubMed]

117. Aiqing, S.; Somayanda, I.; Sebastian, S.V.; Singh, K.; Gill, K.; Prasad, P.; Jagadish, S.K. Heat stress during flowering affects time of day of flowering, seed set, and grain quality in spring wheat. Crop Sci. 2018, 58, 380-392. [CrossRef]

118. Kumar, R.R.; Goswami, S.; Shamim, M.; Mishra, U.; Jain, M.; Singh, K.; Singh, J.P.; Dubey, K.; Singh, S.; Rai, G.K. Biochemical defense response: Characterizing the plasticity of source and sink in spring wheat under terminal heat stress. Front. Plant Sci. 2017, 8, 1603. [CrossRef] [PubMed]

119. Alonso, M.P.; Abbate, P.E.; Mirabella, N.E.; Merlos, F.A.; Panelo, J.S.; Pontaroli, A.C. Analysis of sink/source relations in bread wheat recombinant inbred lines and commercial cultivars under a high yield potential environment. Eur. J. Agron. 2018, 93, 82-87. [CrossRef]

120. Fan, Y.; Ma, C.; Huang, Z.; Abid, M.; Jiang, S.; Dai, T.; Zhang, W.; Ma, S.; Jiang, D.; Han, X. Heat priming during early reproductive stages enhances thermo-tolerance to post-anthesis heat stress via improving photosynthesis and plant productivity in winter wheat (Triticum aestivum L.). Front. Plant Sci. 2018, 9, 805. [CrossRef]

121. Mendanha, T.; Rosenqvist, E.; Hyldgaard, B.; Ottosen, C.-O. Heat priming effects on anthesis heat stress in wheat cultivars (Triticum aestivum L.) with contrasting tolerance to heat stress. Plant Physiol. Biochem. 2018, 132, 213-221. [CrossRef]

122. Zhang, X.; Högy, P.; Wu, X.; Schmid, I.; Wang, X.; Schulze, W.X.; Jiang, D.; Fangmeier, A. Physiological and proteomic evidence for the interactive effects of post-anthesis heat stress and elevated $\mathrm{CO}_{2}$ on wheat. Proteomics 2018, 18, 1800262. [CrossRef] [PubMed]

123. Abdelrahman, M.; Burritt, D.J.; Gupta, A.; Tsujimoto, H.; Tran, L.P. Heat stress effects on source-sink relationships and metabolome dynamics in wheat. J. Exp. Bot. 2020, 71, 543-554. [CrossRef] [PubMed]

124. Impa, S.M.; Sunoj, V.S.J.; Krassovskaya, I.; Bheemanahalli, R.; Obata, T.; Jagadish, S.V.K. Carbon balance and source-sink metabolic changes in winter wheat exposed to high night-time temperature. Plant Cell Environ. 2019, 42, 1233-1246. [CrossRef]

125. Wang, X.; Hou, L.; Lu, Y.; Wu, B.; Gong, X.; Liu, M.; Wang, J.; Sun, Q.; Vierling, E.; Xu, S. Metabolic adaptation of wheat grain contributes to a stable filling rate under heat stress. J. Exp. Bot. 2018, 69, 5531-5545. [CrossRef]

126. Hoffmann-Thoma, G.; van Bel, A.J.; Ehlers, K. Ultrastructure of minor-vein phloem and assimilate export in summer and winter leaves of the symplasmically loading evergreens Ajuga reptans L., Aucuba japonica Thunb., and Hedera helix L. Planta 2001, 212, 231-242. [CrossRef] [PubMed]

127. Schrier, A.A.; Hoffmann-Thoma, G.; van Bel, A.J. Temperature effects on symplasmic and apoplasmic phloem loading and loading-associated carbohydrate processing. Funct. Plant Biol. 2000, 27, 769-778. [CrossRef]

128. Badri, M.A.; Minchin, P.E.; Lapointe, L. Effects of temperature on the growth of spring ephemerals: Crocus vernus. Physiol. Plant. 2007, 130, 67-76. [CrossRef]

129. Lapointe, L. How phenology influences physiology in deciduous forest spring ephemerals. Physiol. Plant. 2001, 113, 151-157. [CrossRef] [PubMed]

130. Gandin, A.; Gutjahr, S.; Dizengremel, P.; Lapointe, L. Source-sink imbalance increases with growth temperature in the spring geophyte Erythronium americanum. J. Exp. Bot. 2011, 62, 3467-3479. [CrossRef]

131. Ohashi, Y.; Nakayama, N.; Saneoka, H.; Fujita, K. Effects of drought stress on photosynthetic gas exchange, chlorophyll fluorescence and stem diameter of soybean plants. Biol. Plant. 2006, 50, 138-141. [CrossRef]

132. Valliyodan, B.; Nguyen, H.T. Understanding regulatory networks and engineering for enhanced drought tolerance in plants. Curr. Opin. Plant Biol. 2006, 9, 189-195. [CrossRef]

133. Porcel, R.; Ruiz-Lozano, J.M. Arbuscular mycorrhizal influence on leaf water potential, solute accumulation, and oxidative stress in soybean plants subjected to drought stress. J. Exp. Bot. 2004, 55, 1743-1750. [CrossRef] [PubMed]

134. Xu, W.; Cui, K.; Xu, A.; Nie, L.; Huang, J.; Peng, S. Drought stress condition increases root to shoot ratio via alteration of carbohydrate partitioning and enzymatic activity in rice seedlings. Acta Physiol. Plant. 2015, 37, 9. [CrossRef]

135. Cui, K.; Huang, J.; Xing, Y.; Yu, S.; Xu, C.; Peng, S. Mapping QTLs for seedling characteristics under different water supply conditions in rice (Oryza sativa). Physiol. Plant. 2008, 132, 53-68. [CrossRef]

136. Hummel, I.; Pantin, F.; Sulpice, R.; Piques, M.; Rolland, G.; Dauzat, M.; Christophe, A.; Pervent, M.; Bouteillé, M.; Stitt, M. Arabidopsis plants acclimate to water deficit at low cost through changes of carbon usage: An integrated perspective using growth, metabolite, enzyme, and gene expression analysis. Plant Physiol. 2010, 154, 357-372. [CrossRef] [PubMed]

137. Liu, H.-S.; Li, F.-M.; Xu, H. Deficiency of water can enhance root respiration rate of drought-sensitive but not drought-tolerant spring wheat. Agric. Water Manag. 2004, 64, 41-48. [CrossRef] 
138. Du, Y.; Zhao, Q.; Chen, L.; Yao, X.; Zhang, W.; Zhang, B.; Xie, F. Effect of drought stress on sugar metabolism in leaves and roots of soybean seedlings. Plant Physiol. Biochem. 2020, 146, 1-12. [CrossRef] [PubMed]

139. Erice, G.; Louahlia, S.; Irigoyen, J.J.; Sanchez-Diaz, M.; Avice, J.-C. Biomass partitioning, morphology and water status of four alfalfa genotypes submitted to progressive drought and subsequent recovery. J. Plant Physiol. 2010, 167, 114-120. [CrossRef]

140. Hesse, B.D.; Goisser, M.; Hartmann, H.; Grams, T.E. Repeated summer drought delays sugar export from the leaf and impairs phloem transport in mature beech. Tree Physiol. 2019, 39, 192-200. [CrossRef]

141. Aliche, E.B.; Theeuwen, T.; Oortwijn, M.; Visser, R.G.F.; van der Linden, C.G. Carbon partitioning mechanisms in POTATO under drought stress. Plant Physiol. Biochem. 2020, 146, 211-219. [CrossRef]

142. Du, Y.; Zhao, Q.; Chen, L.; Yao, X.; Zhang, H.; Wu, J.; Xie, F. Effect of drought stress during soybean R2-R6 growth stages on sucrose metabolism in leaf and seed. Int. J. Mol. Sci. 2020, 21, 618. [CrossRef] [PubMed]

143. Han, A.; Cao, S.; Li, Y.; Wang, H.; Wei, Y.; Shao, X.; Xu, F. Sucrose treatment suppresses programmed cell death in broccoli florets by improving mitochondrial physiological properties. Postharvest Biol. Technol. 2019, 156, 110932. [CrossRef]

144. Cowan, A.K.; Freeman, M.; Björkman, P.-O.; Nicander, B.; Sitbon, F.; Tillberg, E. Effects of senescence-induced alteration in cytokinin metabolism on source-sink relationships and ontogenic and stress-induced transitions in tobacco. Planta 2005, 221, 801-814. [CrossRef]

145. Rizhsky, L.; Liang, H.; Shuman, J.; Shulaev, V.; Davletova, S.; Mittler, R. When defense pathways collide. The response of Arabidopsis to a combination of drought and heat stress. Plant Physiol. 2004, 134, 1683-1696. [CrossRef]

146. Dai, N.; Schaffer, A.; Petreikov, M.; Shahak, Y.; Giller, Y.; Ratner, K.; Levine, A.; Granot, D. Overexpression of Arabidopsis hexokinase in tomato plants inhibits growth, reduces photosynthesis, and induces rapid senescence. Plant Cell 1999, 11, 1253-1266. [CrossRef] [PubMed]

147. Yang, J.; Zhang, J.; Wang, Z.; Zhu, Q.; Liu, L. Abscisic acid and cytokinins in the root exudates and leaves and their relationship to senescence and remobilization of carbon reserves in rice subjected to water stress during grain filling. Planta 2002, 215, 645-652. [CrossRef]

148. Westgate, M.E.; Grant, D.T. Effect of Water Deficits on Seed Development in Soybean: I. Tissue Water Status. Plant Physiol. 1989, 91, 975-979. [CrossRef]

149. Krishnan, P.; Singh, R.; Verma, A.; Joshi, D.; Singh, S. Changes in seed water status as characterized by NMR in developing soybean seed grown under moisture stress conditions. Biochem. Biophys. Res. Commun. 2014, 444, 485-490. [CrossRef] [PubMed]

150. Muller, B.; Pantin, F.; Génard, M.; Turc, O.; Freixes, S.; Piques, M.; Gibon, Y. Water deficits uncouple growth from photosynthesis, increase $C$ content, and modify the relationships between $C$ and growth in sink organs. J. Exp. Bot. 2011, 62, 1715-1729. [CrossRef]

151. Agasse, A.; Vignault, C.; Kappel, C.; Conde, C.; Gerós, H.; Delrot, S. Sugar transport \& sugar sensing in grape. In Grapevine Molecular Physiology \& Biotechnology; Springer: Berlin/Heidelberg, Germany, 2009; pp. 105-139.

152. Peuke, A.D. Correlations in concentrations, xylem and phloem flows, and partitioning of elements and ions in intact plants. A summary and statistical re-evaluation of modelling experiments in Ricinus communis. J. Exp. Bot. 2010, 61, 635-655. [CrossRef] [PubMed]

153. Hu, W.; Loka, D.A.; Fitzsimons, T.R.; Zhou, Z.; Oosterhuis, D.M. Potassium deficiency limits reproductive success by altering carbohydrate and protein balances in cotton (Gossypium hirsutum L.). Environ. Exp. Bot. 2018, 145, 87-94. [CrossRef]

154. Hossain, M.A.; Kamiya, T.; Burritt, D.; Tran, L.-S.P.; Fujiwara, T. Plant Macronutrient Use Efficiency: Molecular and Genomic Perspectives in Crop Plants; Academic Press: Cambridge, MA, USA, 2017.

155. Zhao, H.; Sun, S.; Zhang, L.; Yang, J.; Wang, Z.; Ma, F.; Li, M. Carbohydrate metabolism and transport in apple roots under nitrogen deficiency. Plant Physiol. Biochem. 2020, 155, 455-463. [CrossRef] [PubMed]

156. Ning, P.; Yang, L.; Li, C.; Fritschi, F.B. Post-silking carbon partitioning under nitrogen deficiency revealed sink limitation of grain yield in maize. J. Exp. Bot. 2018, 69, 1707-1719. [CrossRef]

157. Esteban, R.; Ariz, I.; Cruz, C.; Moran, J.F. Mechanisms of ammonium toxicity and the quest for tolerance. Plant Sci. 2016, 248, 92-101. [CrossRef]

158. de Avila Silva, L.; Condori-Apfata, J.A.; Marcelino, M.M.; Tavares, A.C.A.; Raimundi, S.C.J.; Martino, P.B.; Araujo, W.L.; Zsogon, A.; Sulpice, R.; Nunes-Nesi, A. Nitrogen differentially modulates photosynthesis, carbon allocation and yield related traits in two contrasting Capsicum chinense cultivars. Plant Sci. 2019, 283, 224-237. [CrossRef]

159. Takei, K.; Takahashi, T.; Sugiyama, T.; Yamaya, T.; Sakakibara, H. Multiple routes communicating nitrogen availability from roots to shoots: A signal transduction pathway mediated by cytokinin. J. Exp. Bot. 2002, 53, 971-977. [CrossRef] [PubMed]

160. Guo, J.; Jia, Y.; Chen, H.; Zhang, L.; Yang, J.; Zhang, J.; Hu, X.; Ye, X.; Li, Y.; Zhou, Y. Growth, photosynthesis, and nutrient uptake in wheat are affected by differences in nitrogen levels and forms and potassium supply. Sci. Rep. 2019, 9, 1248. [CrossRef]

161. Walch-Liu, P.; Neumann, G.; Bangerth, F.; Engels, C. Rapid effects of nitrogen form on leaf morphogenesis in tobacco. J. Exp. Bot. 2000, 51, 227-237. [CrossRef] [PubMed]

162. Zhou, J.; Wang, M.; Sun, Y.; Gu, Z.; Wang, R.; Saydin, A.; Shen, Q.; Guo, S. Nitrate increased cucumber tolerance to Fusarium wilt by regulating fungal toxin production and distribution. Toxins 2017, 9, 100. [CrossRef]

163. Hermans, C.; Hammond, J.P.; White, P.J.; Verbruggen, N. How do plants respond to nutrient shortage by biomass allocation? Trends Plant Sci. 2006, 11, 610-617. [CrossRef] [PubMed]

164. Liu, J.; Samac, D.A.; Bucciarelli, B.; Allan, D.L.; Vance, C.P. Signaling of phosphorus deficiency-induced gene expression in white lupin requires sugar and phloem transport. Plant J. 2005, 41, 257-268. [CrossRef] [PubMed] 
165. de Groot, C.C.; Marcelis, L.F.; van den Boogaard, R.; Kaiser, W.M.; Lambers, H. Interaction of nitrogen and phosphorus nutrition in determining growth. Plant Soil 2003, 248, 257-268. [CrossRef]

166. Cakmak, I.; Hengeler, C.; Marschner, H. Partitioning of shoot and root dry matter and carbohydrates in bean plants suffering from phosphorus, potassium and magnesium deficiency. J. Exp. Bot. 1994, 45, 1245-1250. [CrossRef]

167. Morales, F.; Pavlovič, A.; Abadía, A.; Abadía, J. Photosynthesis in poor nutrient soils, in compacted soils, and under drought. In The Leaf: A Platform for Performing Photosynthesis; Springer: Berlin/Heidelberg, Germany, 2018; pp. 371-399.

168. Pilot, G.; Gaymard, F.; Mouline, K.; Chérel, I.; Sentenac, H. Regulated expression of Arabidopsis Shaker K+ channel genes involved in $\mathrm{K}+$ uptake and distribution in the plant. Plant Mol. Biol. 2003, 51, 773-787. [CrossRef]

169. Deeken, R.; Geiger, D.; Fromm, J.; Koroleva, O.; Ache, P.; Langenfeld-Heyser, R.; Sauer, N.; May, S.T.; Hedrich, R. Loss of the AKT2/3 potassium channel affects sugar loading into the phloem of Arabidopsis. Planta 2002, 216, 334-344. [CrossRef]

170. Tränkner, M.; Tavakol, E.; Jákli, B. Functioning of potassium and magnesium in photosynthesis, photosynthate translocation and photoprotection. Physiol. Plant. 2018, 163, 414-431. [CrossRef] [PubMed]

171. Cakmak, I.; Yazici, A.M. Magnesium: A forgotten element in crop production. Better Crop. 2010, 94, $23-25$.

172. Koch, M.; Busse, M.; Naumann, M.; Jákli, B.; Smit, I.; Cakmak, I.; Hermans, C.; Pawelzik, E. Differential effects of varied potassium and magnesium nutrition on production and partitioning of photoassimilates in potato plants. Physiol. Plant. 2019, 166, 921-935. [CrossRef] [PubMed]

173. Ding, Y.; Xu, G. Low magnesium with high potassium supply changes sugar partitioning and root growth pattern prior to visible magnesium deficiency in leaves of Rice (Oryza sativa L.). Am. J. Plant Sci. 2011, 2, 601. [CrossRef]

174. Cakmak, I.; Hengeler, C.; Marschner, H. Changes in phloem export of sucrose in leaves in response to phosphorus, potassium and magnesium deficiency in bean plants. J. Exp. Bot. 1994, 45, 1251-1257. [CrossRef]

175. Fischer, E.; Lohaus, G.; Heineke, D.; Heldt, H. Magnesium deficiency results in accumulation of carbohydrates and amino acids in source and sink leaves of spinach. Physiol. Plant. 1998, 102, 16-20. [CrossRef]

176. He, H.; Jin, X.; Ma, H.; Deng, Y.; Huang, J.; Yin, L. Changes of plant biomass partitioning, tissue nutrients and carbohydrates status in magnesium-deficient banana seedlings and remedy potential by foliar application of magnesium. Sci. Hortic. 2020, 268, 109377. [CrossRef]

177. Hermans, C.; Bourgis, F.; Faucher, M.; Strasser, R.J.; Delrot, S.; Verbruggen, N. Magnesium deficiency in sugar beets alters sugar partitioning and phloem loading in young mature leaves. Planta 2005, 220, 541-549. [CrossRef] [PubMed]

178. Gottwald, J.R.; Krysan, P.J.; Young, J.C.; Evert, R.F.; Sussman, M.R. Genetic evidence for the in planta role of phloem-specific plasma membrane sucrose transporters. Proc. Natl. Acad. Sci. USA 2000, 97, 13979-13984. [CrossRef] [PubMed]

179. Xuan, Y.H.; Hu, Y.B.; Chen, L.-Q.; Sosso, D.; Ducat, D.C.; Hou, B.-H.; Frommer, W.B. Functional role of oligomerization for bacterial and plant SWEET sugar transporter family. Proc. Natl. Acad. Sci. USA 2013, 110, E3685-E3694. [CrossRef] [PubMed]

180. Chen, L.-Q.; Hou, B.-H.; Lalonde, S.; Takanaga, H.; Hartung, M.L.; Qu, X.-Q.; Guo, W.-J.; Kim, J.-G.; Underwood, W.; Chaudhuri, B. Sugar transporters for intercellular exchange and nutrition of pathogens. Nature 2010, 468, 527-532. [CrossRef] [PubMed]

181. Durand, M.; Porcheron, B.; Hennion, N.; Maurousset, L.; Lemoine, R.; Pourtau, N. Water deficit enhances C export to the roots in Arabidopsis thaliana plants with contribution of sucrose transporters in both shoot and roots. Plant Physiol. 2016, 170, 1460-1479. [CrossRef]

182. Ibraheem, O.; Dealtry, G.; Roux, S.; Bradley, G. The Effect of Drought and Salinity on the Expressional Levels of Sucrose Transporters in Rice ('Oryza sativa' Nipponbare) Cultivar Plants. Plant Omics 2011, 4, 68.

183. Gowda, V.R.; Henry, A.; Yamauchi, A.; Shashidhar, H.; Serraj, R. Root biology and genetic improvement for drought avoidance in rice. Field Crop. Res. 2011, 122, 1-13. [CrossRef]

184. Poorter, H.; Niklas, K.J.; Reich, P.B.; Oleksyn, J.; Poot, P.; Mommer, L. Biomass allocation to leaves, stems and roots: Meta-analyses of interspecific variation and environmental control. New Phytol. 2012, 193, 30-50. [CrossRef] [PubMed]

185. Voothuluru, P.; Anderson, J.C.; Sharp, R.E.; Peck, S.C. Plasma membrane proteomics in the maize primary root growth zone: Novel insights into root growth adaptation to water stress. Plant Cell Environ. 2016, 39, 2043-2054. [CrossRef]

186. Etxeberria, E.; Pozueta-Romero, J.; Gonzalez, P. In and out of the plant storage vacuole. Plant Sci. 2012, 190, 52-61. [CrossRef]

187. Schulze, W.X.; Schneider, T.; Starck, S.; Martinoia, E.; Trentmann, O. Cold acclimation induces changes in Arabidopsis tonoplast protein abundance and activity and alters phosphorylation of tonoplast monosaccharide transporters. Plant J. 2012, 69, 529-541. [CrossRef]

188. Wang, L.; Yao, L.; Hao, X.; Li, N.; Qian, W.; Yue, C.; Ding, C.; Zeng, J.; Yang, Y.; Wang, X. Tea plant SWEET transporters: Expression profiling, sugar transport, and the involvement of CsSWEET16 in modifying cold tolerance in Arabidopsis. Plant Mol. Biol. 2018, 96, 577-592. [CrossRef]

189. Klemens, P.A.; Patzke, K.; Deitmer, J.; Spinner, L.; Le Hir, R.; Bellini, C.; Bedu, M.; Chardon, F.; Krapp, A.; Neuhaus, H.E. Overexpression of the vacuolar sugar carrier AtSWEET16 modifies germination, growth, and stress tolerance in Arabidopsis. Plant Physiol. 2013, 163, 1338-1352. [CrossRef] [PubMed]

190. Zhang, J.; Li, D.; Xu, X.; Ziska, L.H.; Zhu, J.; Liu, G.; Zhu, C. The potential role of sucrose transport gene expression in the photosynthetic and yield response of rice cultivars to future $\mathrm{CO}_{2}$ concentration. Physiol. Plant 2020, 168, 218-226. [CrossRef] [PubMed]

191. Khush, G.S. Green revolution: The way forward. Nat. Rev. Genet. 2001, 2, 815-822. [CrossRef] [PubMed] 
192. Paul, M.J.; Watson, A.; Griffiths, C.A. Linking fundamental science to crop improvement through understanding source and sink traits and their integration for yield enhancement. J. Exp. Bot. 2020, 71, 2270-2280. [CrossRef]

193. Lander, E.S.; Botstein, D. Mapping mendelian factors underlying quantitative traits using RFLP linkage maps. Genetics 1989, 121, 185-199. [CrossRef] [PubMed]

194. Fernie, A.R.; Gutierrez-Marcos, J. From genome to phenome: Genome-wide association studies and other approaches that bridge the genotype to phenotype gap. Plant J. 2019, 97, 5-7. [CrossRef] [PubMed]

195. Carvalho, F. Pesticides, environment, and food safety. Food Energy Secur. 2017, 6, 48-60. [CrossRef]

196. Paul, M.J.; Oszvald, M.; Jesus, C.; Rajulu, C.; Griffiths, C.A. Increasing crop yield and resilience with trehalose 6-phosphate: Targeting a feast—famine mechanism in cereals for better source-Sink optimization. J. Exp. Bot. 2017, 68, 4455-4462. [CrossRef]

197. Wu, A.; Hammer, G.L.; Doherty, A.; von Caemmerer, S.; Farquhar, G.D. Quantifying impacts of enhancing photosynthesis on crop yield. Nat. Plants 2019, 5, 380-388. [CrossRef]

198. Salesse-Smith, C.E.; Sharwood, R.E.; Busch, F.A.; Kromdijk, J.; Bardal, V.; Stern, D.B. Overexpression of Rubisco subunits with RAF1 increases Rubisco content in maize. Nat. Plants 2018, 4, 802-810. [CrossRef]

199. Pendleton, J.; Smith, G.; Winter, S.; Johnston, T. Field investigations of the relationships of leaf angle in corn (zea mays 1.) to grain yield and apparent photosynthesis 1. Agron. J. 1968, 60, 422-424. [CrossRef]

200. Richards, R.A.; Cavanagh, C.R.; Riffkin, P. Selection for erect canopy architecture can increase yield and biomass of spring wheat. Field Crop. Res. 2019, 244, 107649. [CrossRef]

201. Srivastava, A.C.; Ganesan, S.; Ismail, I.O.; Ayre, B.G. Effective carbon partitioning driven by exotic phloem-specific regulatory elements fused to the Arabidopsis thaliana AtSUC2 sucrose-proton symporter gene. BMC Plant Biol. 2009, 9, 7. [CrossRef] [PubMed]

202. Wingler, A.; Purdy, S.; MacLean, J.A.; Pourtau, N. The role of sugars in integrating environmental signals during the regulation of leaf senescence. J. Exp. Bot. 2006, 57, 391-399. [CrossRef]

203. Rosche, E.; Blackmore, D.; Tegeder, M.; Richardson, T.; Schroeder, H.; Higgins, T.J.; Frommer, W.B.; Offler, C.E.; Patrick, J.W. Seed-specific overexpression of a potato sucrose transporter increases sucrose uptake and growth rates of developing pea cotyledons. Plant J. 2002, 30, 165-175. [CrossRef] [PubMed]

204. Weichert, N.; Saalbach, I.; Weichert, H.; Kohl, S.; Erban, A.; Kopka, J.; Hause, B.; Varshney, A.; Sreenivasulu, N.; Strickert, M. Increasing sucrose uptake capacity of wheat grains stimulates storage protein synthesis. Plant Physiol. 2010, 152, 698-710. [CrossRef] [PubMed]

205. Kaachra, A.; Vats, S.K.; Kumar, S. Heterologous expression of key C and N metabolic enzymes improves re-assimilation of photorespired $\mathrm{CO}_{2}$ and $\mathrm{NH}_{3}$, and growth. Plant Physiol. 2018, 177, 1396-1409. [CrossRef]

206. Naqvi, S.; Zhu, C.; Farre, G.; Ramessar, K.; Bassie, L.; Breitenbach, J.; Conesa, D.P.; Ros, G.; Sandmann, G.; Capell, T. Transgenic multivitamin corn through biofortification of endosperm with three vitamins representing three distinct metabolic pathways. Proc. Natl. Acad. Sci. USA 2009, 106, 7762-7767. [CrossRef] [PubMed]

207. Bachem, C.W.; van Eck, H.J.; de Vries, M.E. Understanding genetic load in potato for hybrid diploid breeding. Mol. Plant 2019, 12, 896-898. [CrossRef]

208. Zhang, C.; Wang, P.; Tang, D.; Yang, Z.; Lu, F.; Qi, J.; Tawari, N.R.; Shang, Y.; Li, C.; Huang, S. The genetic basis of inbreeding depression in potato. Nat. Genet. 2019, 51, 374-378. [CrossRef]

209. Ghosh, S.; Watson, A.; Gonzalez-Navarro, O.E.; Ramirez-Gonzalez, R.H.; Yanes, L.; Mendoza-Suárez, M.; Simmonds, J.; Wells, R.; Rayner, T.; Green, P. Speed breeding in growth chambers and glasshouses for crop breeding and model plant research. Nat. Protoc. 2018, 13, 2944-2963. [CrossRef]

210. Fernie, A.R.; Yan, J. De novo domestication: An alternative route toward new crops for the future. Mol. Plant 2019, $12,615-631$. [CrossRef] [PubMed] 